\title{
A method to predict the cyclic loading profiles (one-way or two-way) for monopile supported offshore wind turbines
}

\author{
Saleh Jalbi ${ }^{1,2}$, Laszlo Arany ${ }^{3}$, AbdelRahman Salem ${ }^{1}$, Liang Cui ${ }^{1}$ and Subhamoy Bhattacharya ${ }^{1}$ \\ ${ }^{1}$ Department of Civil and Environmental Engineering, University of Surrey \\ ${ }^{2}$ Robert Bird Group \\ ${ }^{2}$ Atkins Global \\ Corresponding Author: \\ Professor Subhamoy Bhattacharya \\ Chair in Geomechanics \\ University of Surrey \\ United Kingdom \\ Email: S.Bhattacharya@surrey.ac.uk \\ Phone: 01483689534
}

\begin{abstract}
Monopiles are currently the preferred option for supporting offshore wind turbines (OWTs) in water depths up to about $40 \mathrm{~m}$. Whilst there have been significant advancements in the understanding of the behaviour of monopiles, the guidelines on the prediction of long term tilt (Serviceability Limit State, SLS) under millions of cycles of loads are still limited. Observations and analysis of scaled model tests identify two main parameters that governs the progressive tilt of monopiles: (a) Loading type (one-way or two-way) which can be quantified by the ratio of the minimum to maximum mudline bending moments $\left(\mathrm{M}_{\min } / \mathrm{M}_{\max }\right)$; (b) factor of safety against overturning i.e. the ratio of the maximum applied moment $\left(M_{\max }\right)$ to the moment carrying capacity of the pile or Moment of Resistance $\left(M_{R}\right)$ and therefore the ratio $M_{\max } / M_{R}$. Due to the nature of the environmental loads (wind and wave) and the operating conditions of the turbine, the ratio $\mathrm{M}_{\min } / \mathrm{M}_{\max }$ changes. The aim of this paper is to develop a practical method that can predict the nature of loading for the following governing load cases: Normal Operating Conditions, Extreme Wave Load scenario, and Extreme Wind Load scenario. The proposed method is applied to 15 existing wind farms in Europe where $\left(M_{\min } / M_{\max }\right)$ and $\left(M_{\max } / M_{R}\right)$ are evaluated. The results show that the loading ratio is sensitive to the water depth and turbine size. Furthermore, under normal operating conditions, most of the wind turbine foundations in shallow waters are subjected to one-way loading and in deeper waters and under extreme conditions the loading is marginally two-way. Predictions for the nature of loading for large wind turbines ( $8 \mathrm{MW}$ and $10 \mathrm{MW}$ ) in deeper waters are also presented. The results from this paper can be used for planning scaled model tests and element tests of the soil.
\end{abstract}


Nomenclature

\begin{tabular}{|l|l|}
\hline$A_{R}$ & Rotor swept area \\
\hline$C_{D}$ & Drag coefficient \\
\hline$C_{I}$ & Inertia coefficient \\
\hline$C_{T}$ & Thrust coefficient \\
\hline$C_{u}$ & Soil undrained shear strength \\
\hline$d$ & Point of rotation for rigid piles \\
\hline$D_{p}$ & Pile diameter \\
\hline$H_{m}$ & Extreme wave height \\
\hline$H_{S}$ & Significant wave height \\
\hline$I_{r e f}$ & Reference turbulence intensity \\
\hline$k$ & Wave number \\
\hline$K_{P}$ & Soil passive earth pressure coefficient \\
\hline$L_{K}$ & Integral length scale \\
\hline$L$ & Length of pile \\
\hline$M_{\min }$ & Minimum mudline bending moment \\
\hline$M_{\max }$ & Maximum mudline bending moment \\
\hline$S$ & Average water depth \\
\hline$T_{M}$ & Period for extreme wave height \\
\hline$T_{S}$ & Period for significant wave height \\
\hline$M_{R}$ & Ultimate moment resistance \\
\hline$U_{R}$ & Rated wind speed \\
\hline$U_{\text {hub }}$ & Wind speed at hub height \\
\hline $\bar{U}$ & Mean wind speed \\
\hline$W$ & Velocity of wave particle \\
\hline$Z_{h u b}$ & Hub height \\
\hline$\eta$ & Wave surface elevation \\
\hline$V^{\prime}$ & Buoyant unit weight of the soil \\
\hline$\phi^{\prime}$ & Angle of internal friction \\
\hline$\sigma_{V}^{\prime}$ & Vertical effective stress \\
\hline$\sigma_{U}$ & Standard deviation \\
\hline$\rho_{a}$ & Density of air \\
\hline$\rho_{w}$ & Density of water \\
\hline$\omega$ & Frequency of wave \\
\hline & \\
\hline
\end{tabular}




\subsection{Introduction}

Offshore wind turbines are currently implemented as practical sources of energy with a low carbon footprint. Foundations are considered to be an expensive item in the overall cost breakdown of an offshore windfarm, with the foundation, substructure, assembly, and installation covering a staggering 25 to $34 \%$ of the total cost (Bhattacharya, 2013) (Stehly, et al., 2017). This was one of the main drivers for extensive research and industrial efforts to reduce the Levelized Cost of Energy (LCOE). Based on the 2017 auction price, the cost of megawatt hour of energy produced from offshore wind farms was cheaper than that produced by a nuclear power plant and set to compete with other sources of energy such as natural gas in the near future (Harrabin, 2017). Monopiles are currently the preferred option for supporting OWTs in water depths up to about $40 \mathrm{~m}$ and are even considered for deeper waters. These foundations are to be designed to resist certain levels of deformations and long-term tilt and are summarized below:

1. The initial tilt of the monopile due to installation has to be within the allowed limit (current limit set in DNV code is $0.25^{\circ}$ ).

2. The accumulated tilt due to millions of load cycles during the lifetime of the turbine has to be within the allowed limit (current limit is $0.25^{\circ}$ ). Alternaltively, the total tilt i.e. initial + accumulated at the nacelle level is limited (current limit is $0.5^{\circ}$ ).

3. The initial deflection at the monopile head (mudline/seabed level) has to be within the allowed limit (e.g. 0.1m).

4. The accumulated deflection at the monopile head (mudline/seabed level) has to be within the allowed limit (e.g. $0.1 \mathrm{~m}$ ). Alternatively, the total pile deflection at mudline (initial + accumulated) is limited (e.g. $0.2 \mathrm{~m}$ ).

The readers are referred to (Bhattacharya, 2019) and Arany et al (2017) for further details. If these limits are exceeded, the warranty from turbine manufacturers might be lost leading to possible financial implications for windfarm developers. Therefore, reliable methods to estimate long term tilt are essential for cost effective solutions. Design standards such as the (API, 2007) and the (DNV, 2014) do not have a comprehensive method to predict rotation accumulation due to cyclic loading. Instead they present methods to adjust $p$-y curves by reducing the soil stiffness in order to incorporate the effect of cyclic loading. Furthermore, API method is calibrated against slender-small diameter piles for low number of loading cycles, which does not present an accurate idealization of current monopiles supporting OWTs. Figure 1 shows a simple schematic representation of mudline bending moment acting on a monopile which is effectively a superposition of wind and the wave loading. The work of Arany et al (2015) showed that moment due to $1 \mathrm{P}$ and $3 \mathrm{P}$ are orders of magnitude lower than the wind and wave and can be ignored for tilt calculations.

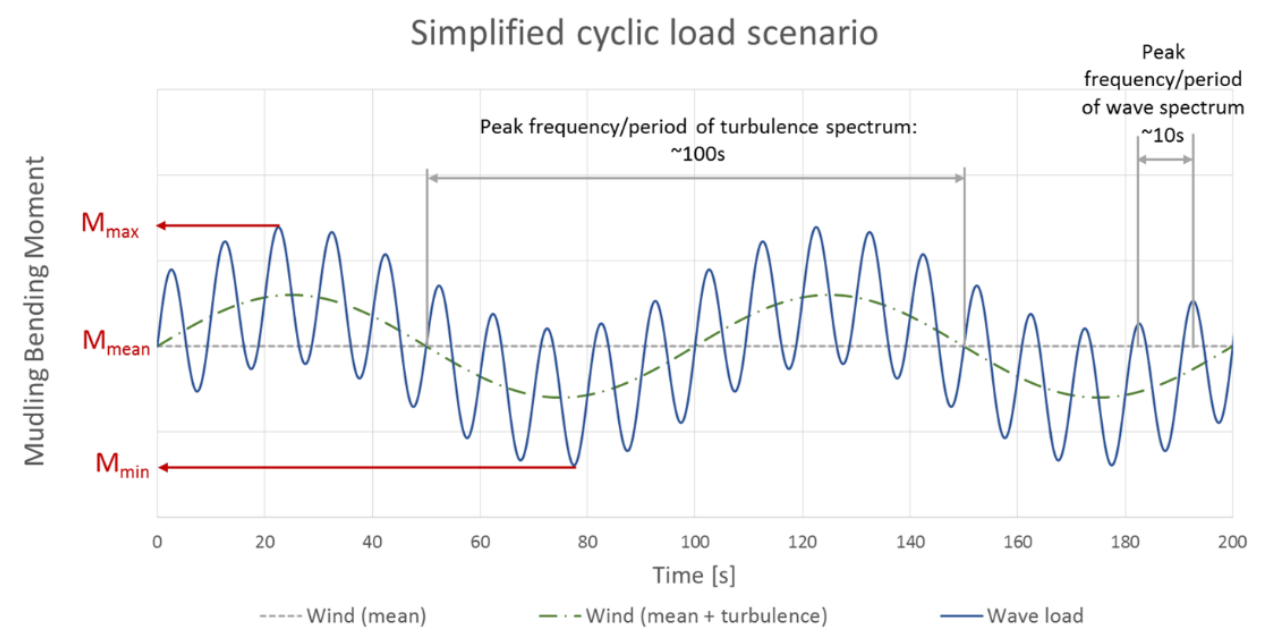

Figure 1: Simplified time history of the mudline bending moments following

Scaled model tests have been carried out in the last decade, see for example (Leblanc, et al., 2010) (Rudolph, et al., 2014) (Cox \& Bhattacharya, 2017) for establishing methodologies for the assessment of the long-term performance (deflection and tilting) for monopiles. The main parameters affecting tilt are the ratio of $M_{\min } / M_{\max }$ and $M_{\max } / M_{R}$. The definition of $M_{\min }$ and $M_{\max }$ are provided in Figure 1 and is also explained later in the paper. $M_{R}$ is the ultimate moment capacity of the pile considering soil failure and strictly not the failure of the pile through local buckling or yielding. The load cases (i.e. $M_{\min } / M_{\max }$ and $M_{\max } / M_{R}$ ) used in most of these scaled tests show a wide range from extreme one-way loading to extreme two-way loading and often unrealistic loading range.

Therefore, the aim and scope of this paper is to provide general recommendations on the loading profiles (one-way vs two-way loading) and loading intensity $\left(\mathrm{M}_{\max } / \mathrm{M}_{\mathrm{R}}\right)$ for future scaled model studies on long term tilt. The proposed 
method follows the work of (Arany, et al., 2017)and (Arany \& Bhattacharya, 2018) where a relatively simple method is used to estimate wind and wave loads on foundations for OWTs. The paper is structured in the following way:

1. Provide an overview of loads acting on OWTs and present simplified methods to obtain cyclic load profiles acting on the foundation.

2. Provide a simplified method to obtaining moment carrying capacity of the monopile (i.e. estimation of $M_{R}$ ).

3. Apply the proposed methodology to 15 wind turbines to evaluate the loading profile together with a brief summary of the recent efforts of estimating long term tilt and their findings.

\subsection{Loads acting on OWTs}

Figure 2 shows schematic diagram of the main cyclic/dynamic loads acting on a wind turbine along with a simplified time-history. The main loads that cause overturning moment are: mean and turbulent component of wind loading, wave loading, loading due to rotor (1P) effects owing to mass and aerodynamic imbalances of the rotor, load due to blade passing (3P). As mentioned before the wind and wave loads are dominant in terms of magnitude and would therefore contribute to the long-term tilt and is considered in the analysis.
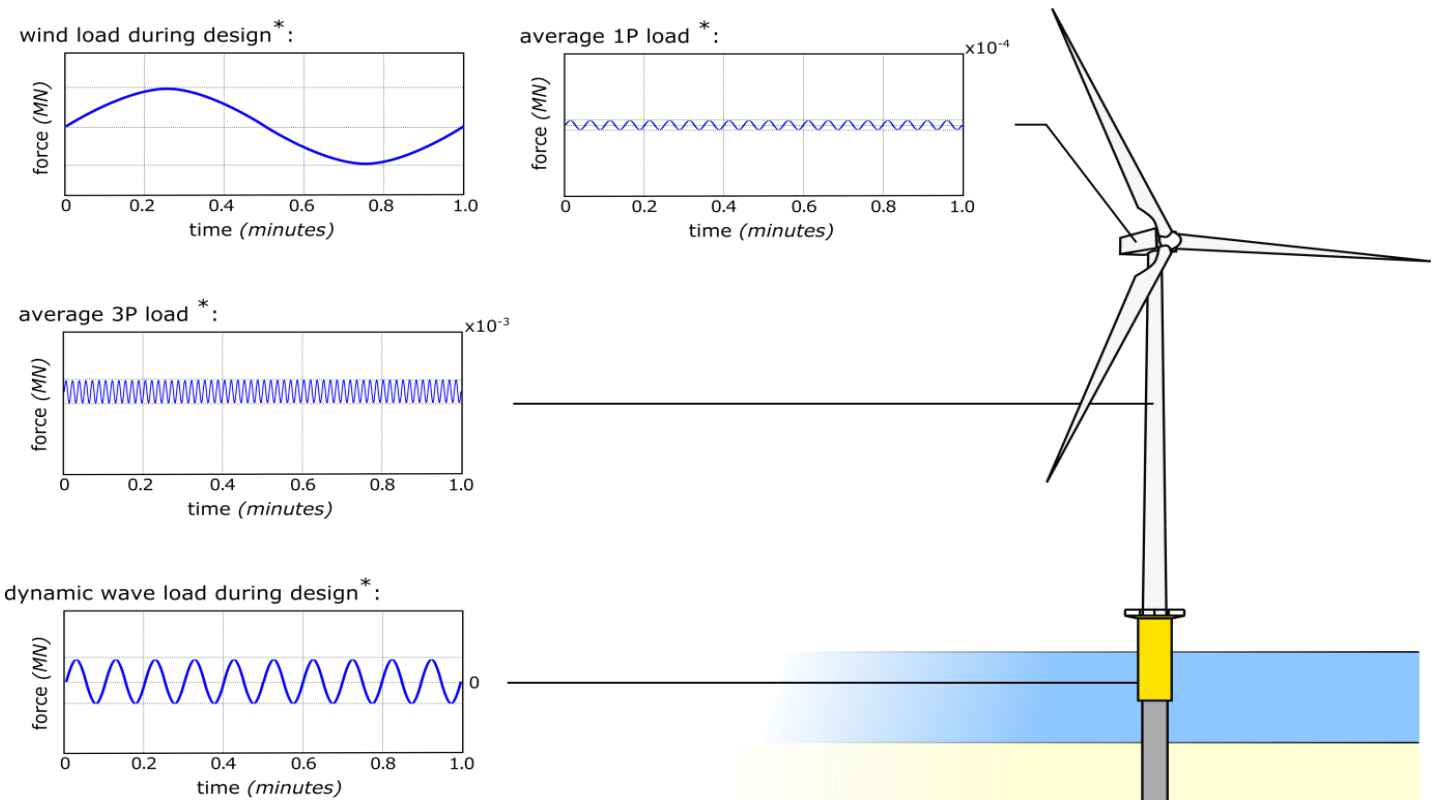

*these values are just indicating the magnitude of the different quantities

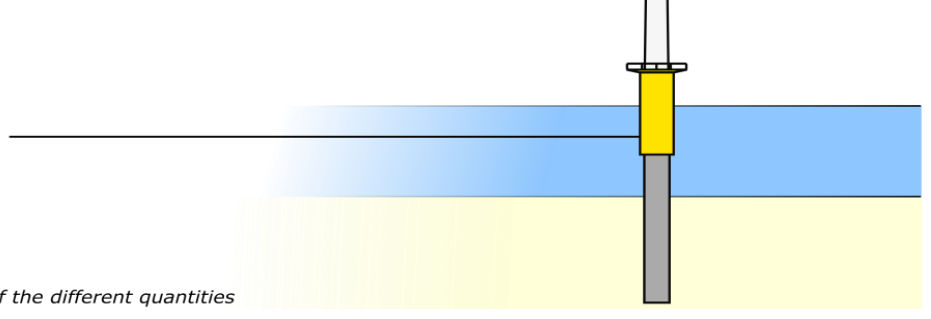

Figure 2: Schematic of loads acting on monopile supported OWTs following (Bhattacharya, et al., 2017)

It is worth noting that most of the energy content in the wind turbulence is in the low frequency regions away from the eigen-frequencies of the structure. On the other hand, wave loads are dynamic and thus the inertia effects and dynamic amplification must be taken into account.

Figure 3(a) shows an example time history of wind speed and the corresponding thrust force on the rotor is shown in Figure 3(b) which is obtained from aero-servo-hydro-elastic analyses. As shown in the figures, the variance in the wind loading contains variations with various frequencies (or time periods), however, the largest variations have a period in the 1-3 minutes range. Figure 3(c) shows the mudline bending moment in the pile. 


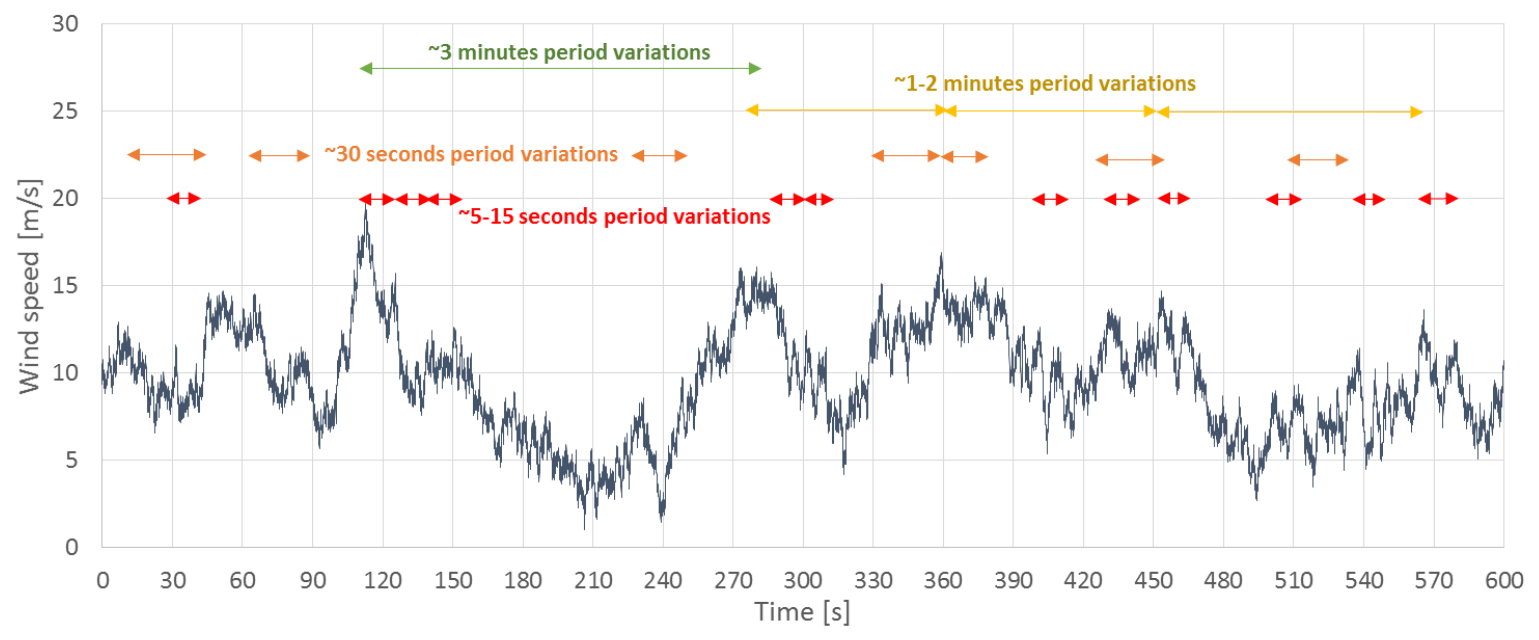

Figure 3(a): Wind speed time history input for aero-servo-hydro-elastic analysis

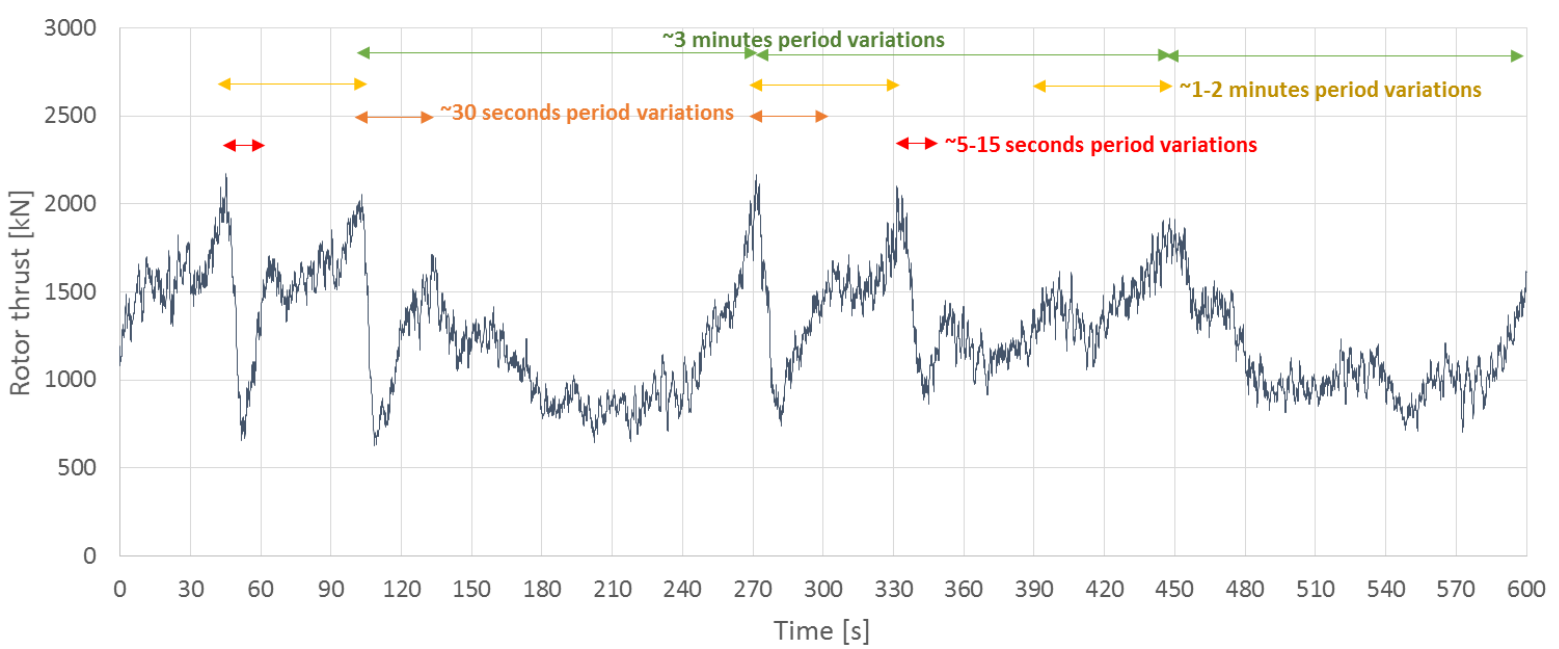

Figure 3(b): Thrust force on the rotor resulting from the wind speed time history in Figure 3(a).

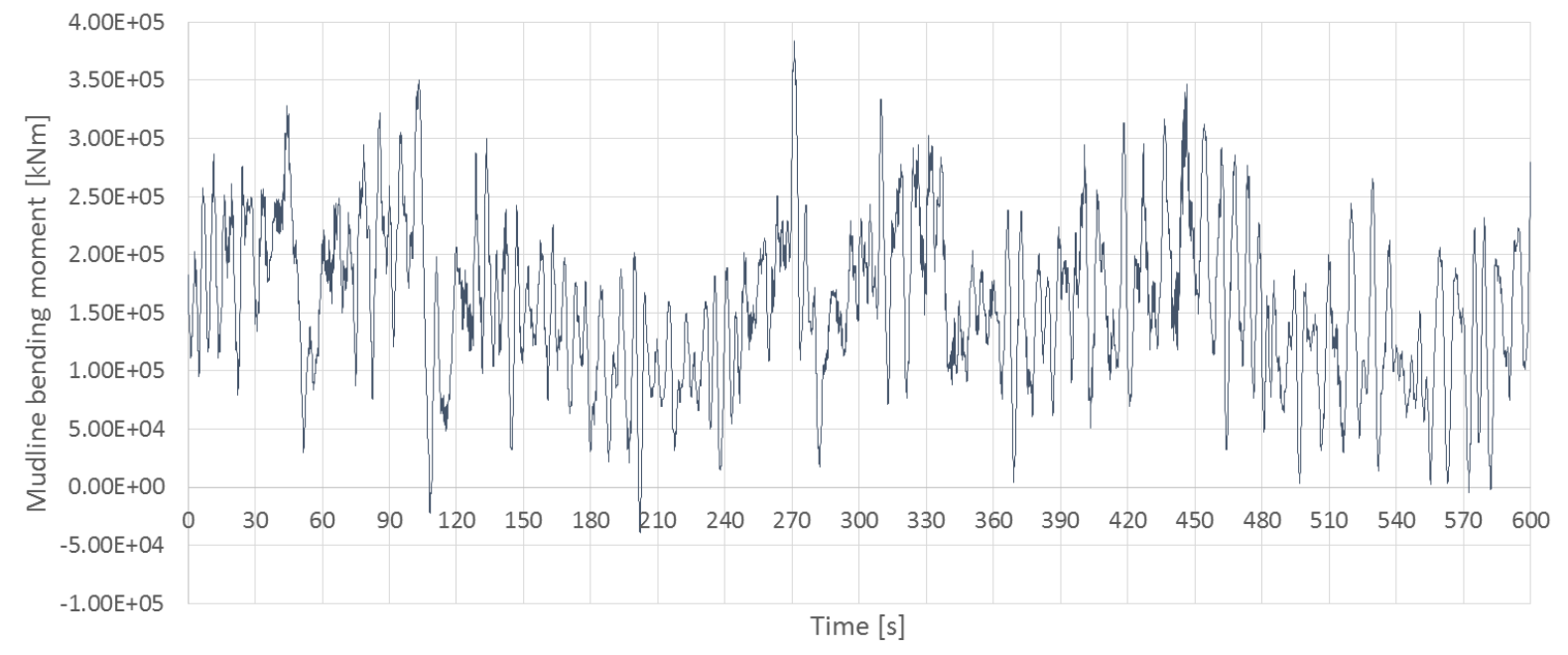

Figure 3(c): Mudline Bending Moment acting on the pile

The peak period of wind turbulence spectra around the rated wind speed of typical wind turbines is around 100s and is the basis of construction of the simplified schematic load time history shown in Figure 1. It may be noted that these loads may also act in different directions. From Figure 1, the following parameters are important: maximum mudline bending moment $\left(M_{\max }\right)$, minimum mudline bending moment $\left(M_{\min }\right)$ and frequency of loading. Scaled model tests suggest that the ratio of $\mathrm{M}_{\min } / \mathrm{M}_{\max }$ has a dominant effect on the accumulation of tilt, which means that a general understanding of the loads on current windfarms is crucial. Deterministic load calculation methods developed by (Arany, 
et al., 2015) (Arany, et al., 2017), and (Arany \& Bhattacharya, 2018) based on statistical variations of wind and waves described in the IEC 61400 and DNGL-ST-0437 codes can be used to get a preliminary understanding of the loading profiles. The next sections provide an overview of the load cases considered and wind/wave load calculation methods.

\subsection{Load Cases}

Numerous load cases are provided in the DNV as well as the IEC codes for the design of offshore wind turbines to serve a service life of 25-30 years, however only few are relevant to foundation design. Several load cases are derived from those provided in DNVGL-ST-0437 for this study, and are shown in Table 1:

Table 1: Load Scenarios chosen for this study

\begin{tabular}{|l|l|l|}
\hline \multicolumn{1}{|c|}{ Name } & \multicolumn{1}{|c|}{ Wind Model } & \multicolumn{1}{c|}{ Wave Model } \\
\hline Normal Operational Conditions & $\begin{array}{l}\text { Normal Turbulence Model } \\
(N T M) \text { at the rated wind speed } \\
\left(U_{R}\right)\end{array}$ & 1-Year Extreme Sea State (ESS) \\
\hline Extreme Wave Load Scenario & $\begin{array}{l}\text { Extreme Turbulence Model } \\
(E T M) \text { at the rated wind speed } \\
\left(U_{R}\right)\end{array}$ & 50-Year Extreme Wave Height (EWH) \\
\hline Extreme Wind Load Scenario & $\begin{array}{l}\text { Extreme Operating Gust (EOG) } \\
\text { at the rated wind speed }\left(U_{R}\right)\end{array}$ & 1-Year Extreme Wave Height (EWH) \\
\hline
\end{tabular}

\section{Note: The wind and wave loads are taken as collinear}

The wave conditions are considered independent of the wind conditions. However, in reality this is not necessarily a true reflection of the problem as storms typically bring high waves and high winds at the same time. It may be noted that this assumption is conservative as the maximum thrust force on the rotor does not correspond to the highest wind speeds but those close to the rated wind speed, see (Arany, et al., 2017). Moreover, even though the loads are assumed to be collinear, in reality the misalignment between wind and waves might vary up to $90^{\circ}$ (Siedel, 2010). While this misalignment is significant for fatigue life estimation, the magnitude of misaligned load cycles is unlikely to contribute significantly to accumulated tilt, based on the lowest load magnitudes $\left(M_{\max } / M_{R}\right)$ where accumulated tilt was shown to occur in scale model tests as the one presented in (Leblanc, et al., 2010). However, it should be noted that a varying angular direction of the same load (i.e. same $M_{\min } / \mathrm{M}_{\max }$ load applied in different angles) may result in higher deformation as shown in (Rudolph, et al., 2014). Further information on long term tilt is presented in Section 4.

The wind loads are generally assumed to be quasi-static, hence they are formed of a mean wind speed and a turbulent (deviated) component as shown in Eq.1 where $\bar{U}$ is the mean wind speed and $\mathrm{u}$ is the turbulent component. These values depend on the probability distribution and are related to wind models shown in Table 1 and further expressed in Table 2.

$$
\mathrm{U}=\bar{U}+\mathrm{u}
$$

\section{Table 2: Description of wind and wave models}

\begin{tabular}{|l|l|}
\hline \multicolumn{2}{|c|}{ Wind Models } \\
\hline Normal Turbulence Model (NTM) & $\begin{array}{l}\text { The mean wind speed } \bar{U} \text { is } \cup_{R} \text { which leads to the highest thrust } \\
\text { force at hub level. The turbulent component } u \text { is modelled by } \\
\text { the NTM standard deviation of wind speed as defined in the IEC } \\
\text { code. }\end{array}$ \\
\hline Extreme Turbulence Model (ETM) & $\begin{array}{l}\text { The mean wind speed } \bar{U} \text { is } U_{R} \text { which leads to the highest thrust } \\
\text { force at hub level. The turbulent component } u \text { is modelled by } \\
\text { the ETM standard deviation of wind speed as defined in the } \\
\text { DNVGL-ST-0437. This results in a high value for the turbulent }\end{array}$ \\
\hline
\end{tabular}




\begin{tabular}{|c|l|}
\hline & $\begin{array}{l}\text { component of the wind speed, which results in a higher value } \\
\text { for the maximum thrust force. }\end{array}$ \\
\hline Extreme Operating Gust (EOG) & $\begin{array}{l}\text { A gust is a sudden change in the wind speed over a certain } \\
\text { period of time. Modern wind turbines have the ability to shut } \\
\text { down at high wind speeds and thus relieving the loads. } \\
\text { However, for a conservative estimate, the mean wind speed } \bar{U} \\
\text { is } U_{R} \text { and the turbulent component } u \text { is chosen based on the } \\
\text { operating gust speed formulation of IEC }\end{array}$ \\
\hline \multicolumn{2}{|c|}{ Wave Models } \\
\hline 1-Year Extreme Sea States (ESS) & $\begin{array}{l}\text { The wave height used in computing the wave loads is the 1-year } \\
\text { significant wave height } \mathrm{H}_{\mathrm{s}, 1}\end{array}$ \\
\hline 1-Year Extreme Wave Height \\
(EWH) & $\begin{array}{l}\text { The wave height used in computing the wave loads is the 1-year } \\
\text { extreme wave height } \mathrm{H}_{\mathrm{m}, 1}\end{array}$ \\
\hline (EWH) & $\begin{array}{l}\text { The wave height used in computing the wave loads is the 50- } \\
\text { year extreme wave height } \mathrm{H}_{m, 50}\end{array}$ \\
\hline
\end{tabular}

With reference to Table 2 , the significant wave height $\mathrm{H}_{\mathrm{s}}$ is the average of the highest $1 / 3$ of all waves during a specific frame of time defined by codes (usually taken as the 3-hour sea state). The maximum wave height $\mathrm{H}_{\mathrm{m}}$ is the highest peak in that time frame. Details on how the deterministic wind and wave loads are computed using the probabilistic distributions of the models shown in Table 1 and Table 2 are discussed in the next sections 2.2 and 2.3.

\subsection{Wind Loads (General Solution):}

The thrust force on a wind turbine can be estimated using Eq.2

$\mathrm{Th}=\frac{1}{2} \rho_{\mathrm{a}} \mathrm{A}_{\mathrm{R}} \mathrm{C}_{\mathrm{T}} \mathrm{U}^{2}$

Where $A_{R}$ is the swept area of the rotor, $C_{T}$ is the thrust coefficient, $\rho_{a}$ is the density of air, and $U$ is the wind speed. As shown in Eq.1, the wind speed can be replaced with a quasi-static formulation, moreover, the load cases employed in this study consider the mean wind speed equal to the rated wind speed $U_{R}$, hence Eq.2 may be written as

$\mathrm{Th}=\frac{1}{2} \rho_{\mathrm{a}} \mathrm{A}_{\mathrm{R}} \mathrm{C}_{\mathrm{T}}\left(\mathrm{U}_{\mathrm{R}}+\mathrm{u}\right)^{2}$

At the rated wind speed the thrust coefficient $C_{T}$ (assuming the power is constant):

$\mathrm{C}_{\mathrm{T}}=\frac{3.5\left(2 \mathrm{U}_{\mathrm{R}}+3.5\right)}{\mathrm{U}_{\mathrm{R}}{ }^{2}}$ Where the speeds are expressed in $\mathrm{m} / \mathrm{s}$

The only variable remaining to estimate the thrust force is the turbulent component of the wind speed u which depends on the wind model shown in Table 1. Arany et al (2017) showed the methodology of estimating loads through an illustrated example.

\subsection{Wave Loads (General Solution):}

The general solution for estimating the wave loads is given by first assuming that the wave particle motion is following linear (Airy) wave theory. This gives the equation of surface elevation shown in Eq.5, where $H$ is the wave height, $T$ is the wave period, $k$ is the wave number related to the wave length through $\frac{2 \pi}{\mathrm{L}}, \mathrm{t}$ is time in seconds, and $\mathrm{x}$ is the horizontal distance from the pile as shown in Figure 4. 


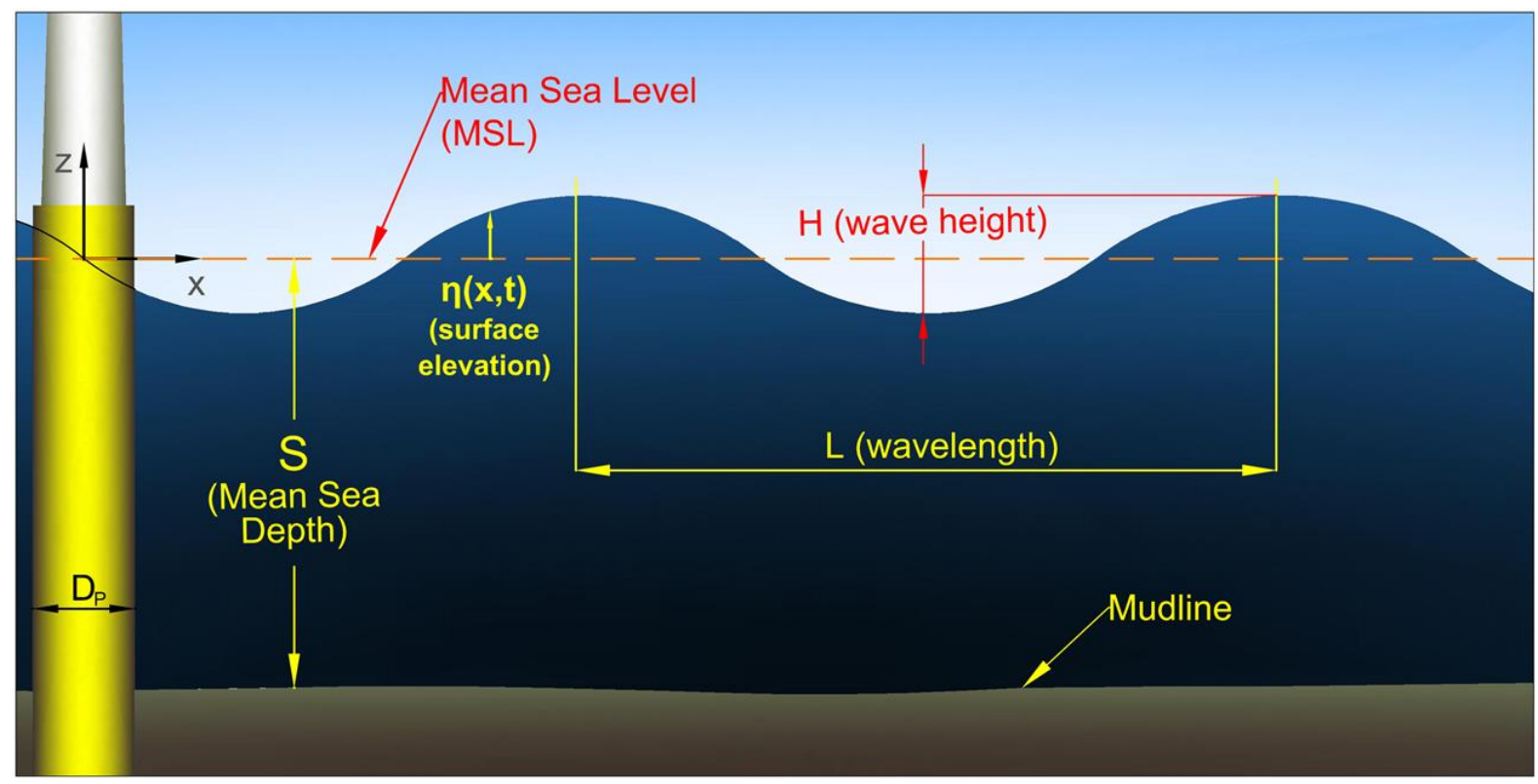

Figure 4: Schematic for wave parameters following (Arany, et al., 2015)

$\eta=\frac{\mathrm{H}}{2} \cos \left(\frac{2 \pi \mathrm{t}}{\mathrm{T}}-\mathrm{kx}\right)$

The velocity $\mathrm{w}$ and acceleration $\dot{w}$ of the water particle at a given time $\mathrm{t}$ at a distance $\mathrm{x}$ from the origin are given in Eq.6-7

$$
\begin{aligned}
& w=\frac{\pi \mathrm{H} \cosh (\mathrm{k}(\mathrm{S}+\mathrm{z}))}{\mathrm{T} \sinh (\mathrm{kS})} \cos \left(\frac{2 \pi \mathrm{t}}{\mathrm{T}}-\mathrm{kx}\right) \\
& \dot{w}=\frac{-2 \pi^{2} \mathrm{H} \cosh (\mathrm{k}(\mathrm{S}+\mathrm{z}))}{\mathrm{T}^{2} \sinh (\mathrm{kS})} \sin \left(\frac{2 \pi \mathrm{t}}{\mathrm{T}}-\mathrm{kx}\right)
\end{aligned}
$$

The wave number can be obtained from the frequency equation shown in Eq.8

$\omega^{2}=\operatorname{gktanh}(\mathrm{kS})$ Such that $\omega=\frac{2 \pi}{\mathrm{T}}$

On the other hand, Morison's equation (Morison, et al., 1950) as shown in Eq.9 (where the velocity w and acceleration $\dot{w}$ from Eq.6-7 may be substituted) is compute the wave force on a unit strip of the submerged pile.

$\mathrm{dF}_{\text {wave }}=\mathrm{dF}_{\mathrm{D}}+\mathrm{dF}_{\mathrm{I}}=\frac{1}{2} \rho_{\mathrm{w}} \mathrm{D}_{\mathrm{P}} \mathrm{C}_{\mathrm{D}} \mathrm{w}|\mathrm{w}|+\frac{1}{4} \pi \rho_{\mathrm{w}} \mathrm{D}_{\mathrm{p}}^{2} \mathrm{C}_{\mathrm{m}} \mathrm{w}$

Where $D_{P}$ is the diameter of the pile, $\rho_{w}$ is the density of water, $C_{D}$ and $C_{m}$ are the drag and inertia coefficients respectively. Thus, it may be noticed that the force is formed of two components, namely the drag and inertia terms. In engineering practice, the drag and inertia coefficients are assumed to be constant where typical values for the $C_{D}$ range from 0.6 to 1.0 and 1.5 to 2.0 for $C_{m}$ (Dawson, 1983). For this work, the values of $C_{D}$ and $C_{m}$ were conservatively taken as 1.0 and 2.0 respectively.

The total horizontal force exerted on the submerged length of the pile from -S to $n$ (see Figure 4) may be computed using Eq.10

$F_{\text {wave }}(t)=\int_{-S}^{\eta} d F_{D} d z+\int_{-S}^{\eta} d F_{I} d z$

The moment is then computed by multiplying by the lever arm as shown in (Eq.11) 
$M_{\text {wave }}(t)=\int_{-S}^{\eta} d F_{D}(S+\eta) d z+\int_{-S}^{\eta} d F_{I}(S+\eta) d z$

It is evident from Eq.10-11 that the maximum drag and inertia forces occur at different instances of time and surface elevation. The maximum inertia force occurs at $\mathrm{t}=0$ and $\eta=0$ whilst the maximum drag force occurs at $\eta=\mathrm{H} / 2$ and $\mathrm{t}=\mathrm{T} / 4$. By performing the integrations shown in Eq.10-11 and substituting the appropriate values for $t$ and $\eta$, the maximum drag force and moment are obtained using Eq.12-13

$$
\begin{aligned}
& \mathrm{F}_{\mathrm{D}, \max }=\left[\frac{1}{2} \rho_{\mathrm{w}} \mathrm{D}_{\mathrm{S}} \mathrm{C}_{\mathrm{D}} \frac{\pi^{2} \mathrm{H}^{2}}{\mathrm{~T}^{2} \sinh ^{2}(\mathrm{kS})}\right]\left[\frac{\mathrm{e}^{2 \mathrm{k}(\mathrm{S}+\eta)}-\mathrm{e}^{-2 \mathrm{k}(\mathrm{S}+\eta)}}{8 \mathrm{~K}}+\frac{\mathrm{S}+\eta}{2}\right] \\
& \mathrm{M}_{\mathrm{D}, \max }=\left[\frac{1}{2} \rho_{\mathrm{w}} \mathrm{D}_{\mathrm{S}} \mathrm{C}_{\mathrm{D}} \frac{\pi^{2} \mathrm{H}^{2}}{\mathrm{~T}^{2} \sinh ^{2}(\mathrm{kS})}\right]\left[\left(\frac{\mathrm{S}+\eta}{8 \mathrm{k}}-\frac{1}{16 \mathrm{k}^{2}}\right) \mathrm{e}^{2 \mathrm{k}(\mathrm{S}+\eta)}-\left(\frac{\mathrm{S}+\eta}{8 \mathrm{k}}+\frac{1}{16 \mathrm{k}^{2}}\right) \mathrm{e}^{-2 \mathrm{k}(\mathrm{S}+\eta)}+\left(\frac{\mathrm{S}+\eta}{2}\right)^{2}\right]
\end{aligned}
$$

Similarly, the maximum inertia forces are in Eq.14-15

$$
\begin{aligned}
& \mathrm{F}_{\mathrm{I}, \max }=\left[\frac{1}{2} \rho_{\mathrm{w}} \mathrm{D}_{\mathrm{S}} \mathrm{C}_{\mathrm{m}} \frac{\pi^{3} \mathrm{H}}{\mathrm{T}^{2} \sinh (\mathrm{kS})}\right]\left[\frac{\sinh (\mathrm{k}(\mathrm{S}+\mathrm{h}))}{\mathrm{k}}\right] \\
& \mathrm{M}_{\mathrm{D}, \max }=\left[\frac{1}{2} \rho_{\mathrm{w}} \mathrm{D}_{\mathrm{S}} \mathrm{C}_{\mathrm{D}} \frac{\pi^{3} \mathrm{H}}{\mathrm{T}^{2} \sinh (\mathrm{kS})}\right]\left[\left(\frac{\mathrm{S}+\eta}{2 \mathrm{k}}-\frac{1}{2 \mathrm{k}^{2}}\right) \mathrm{e}^{\mathrm{k}(\mathrm{S}+\eta)}-\left(\frac{\mathrm{S}+\eta}{2 \mathrm{k}}+\frac{1}{2 \mathrm{k}^{2}}\right) \mathrm{e}^{-\mathrm{k}(\mathrm{S}+\eta)}+\left(\frac{1}{\mathrm{k}}\right)^{2}\right]
\end{aligned}
$$

Even though the maximum drag and inertia maximum bending moments occur at different instances of time, they will be added directly to obtain a conservative estimate of the moment due to wave load. As it can be seen from the maximum moment equations, all parameters depend on the wave height $\mathrm{H}$ and the period $\mathrm{T}$. The values of these will be dictated by wave model selected as shown in Table 1. Details of the methodology along with example application is provided in Arany et al (2017) and Arany and Bhattacharya (2018).

It may be noted that the methods expressed in section 2.2 and 2.3 are simplistic and have numerous assumptions and simplifications. The advantage lies in requiring the minimum amount of input and processing time to get a reasonable loading history on wind turbine foundations. In reality, one must carry out complex operations using aero-servo-elastic simulations which require much more complex formulations and input such as accurate drag and inertia coefficients, site specific wind and wave readings, probability distribution models which best suit a given site, and accurate tower and blade geometry.

\subsection{Estimating Ultimate Moment Resistance $M_{R}$}

The ultimate moment that can be resisted by a pile is a function of the ultimate lateral resistance that can be mobilized by the soil against the pile. The mobilized soil resistance of a laterally moving pile is characterized by two failure mechanisms. The first occurs at shallow depths and is due to the formation of a passive wedge in front of the pile (in the direction of loading) and a gap behind it. The second is associated with the plastic flow of soil around the pile in the horizontal plane which occurs at deeper levels, see Figure 5. 


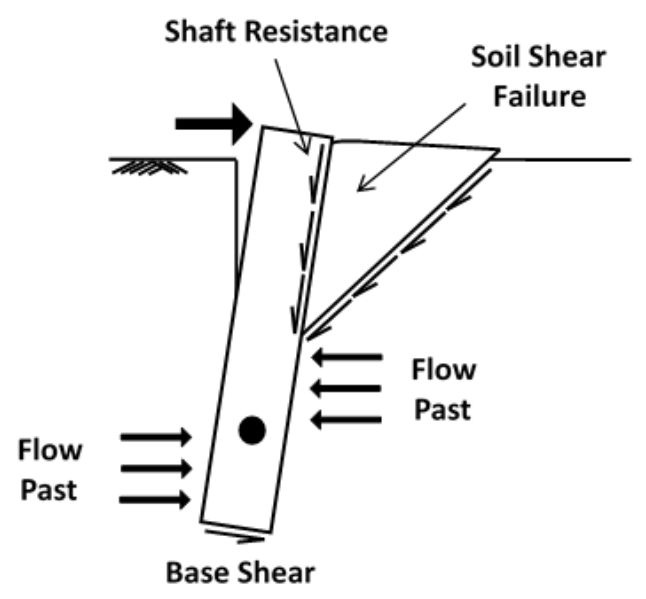

Figure 5: Soil failure due to lateral loads

As this is a 3D problem and non-linear, the solutions presented in literature are semi-empirical or expressions with idealized simplifications (Jamiolkowski \& Garassino, 1977). For instance, Figure 6 shows a schematic of idealized ultimate pressure distributions of a rigid laterally loaded pile in cohesionless ground profiles obtained from different sources in literature. From the figure, it can be seen that the methods available frequently produce different results, making it difficult for practicing engineers to accurately predict the value of $\mathrm{p}_{u}$ (Zhang, et al., 2005) . Moreover, the soil is idealized as a rigid plastic material with the limiting pressures having sharp transitions which is also an idealization of the real problem (Fleming, et al., 1992). The accurate estimation of the ultimate lateral and moment capacity of a pile has not been a major concern in previous studies (which were mostly tailored for the oil and gas industry) as the deformation limit would be exceeded before the ultimate limit (Poulos \& Davies, 1980). Hence, any conservative estimate of the ultimate strength would have sufficed. This is not the case for wind turbines as there is some evidence in literature that the ultimate moment resistance affects the long term tilt in cohesionless soils as will be discussed in Section 4. A solution to this would be the use of 3D advanced finite element analysis (FEA), but this could prove to be relatively costlier and time consuming than the simplified methods and is more suitable in the detailed design stage. Moreover, FEA relies on complex constitutive soil models which means that expert judgement is required in the selection and application of such models to obtain the ultimate failure pressure $\mathrm{p}_{\mathrm{u}}$.

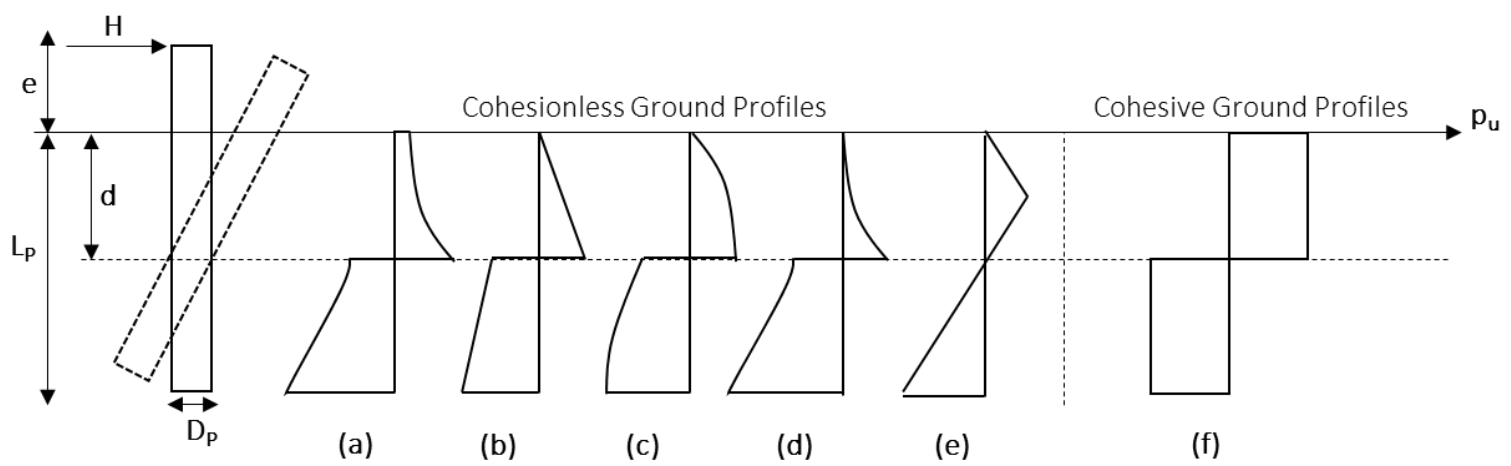

Figure 6: idealized distribution of $\mathrm{p}_{\mathrm{u}}$ with depth by (a) (Brinch Hansen, 1961) (b) (Broms, 1964) (c) (Fleming, et al., 1992) (d) (Reese, et al., 1974) (e) (Prasad \& Chari, 1999) (f) (Broms,1964b)

Rigid and flexible (slender) piles behave differently. Rigid piles are short and bulky enough to undergo rigid body rotation in the soil under operational loads, instead of bending like a clamped beam, and the shear strength of the soil governs the design (soil fails before the pile). Slender/ "infinitely" long piles undergo deflection under operating loads and fail typically through plastic hinge formation. The pile toe generally doesn't "feel" the effect of lateral loads at the mudline when the pile has exceeds the so called critical length. The concept of critical length has been introduced by some researches to differentiate the rigid from flexible behaviour. This depends on the ratio of the foundation to soil stiffness where for instance, based on the elastic continuum approach, (Randolph, 1981) proposed some formulations that are

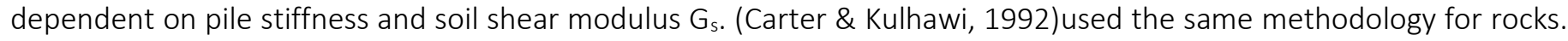


(Poulos \& Davies, 1980) provided expressions which depend on the modulus of subgrade reaction $k_{h}$ and pile stiffness. Recently, (Shadlou \& Bhattacharya, 2016) provided charts to determine whether a pile is rigid or flexible depending on the ratio of $E_{s o}$ and $E_{p}$. The problem with these methods is the uncertainty of their applications for multi-layered soils and the wide range of differences in results.

\subsection{Estimating the Ultimate resisting moment of a pile $M_{R}$}

The resistance to overturning is a function of the pile dimensions, pile yield strength, and ultimate lateral resistance of a soil. The ultimate moment at which the system fails due to the soil can be taken as the summation of the moments of the ultimate soil pressures. Hence as shown in Figure 6, different sources in literature give different solutions to $p_{u}$ which will give different estimates of $M_{R}$. For the sake of practicality, commercial software package ALP (Analysis of Laterally Loaded Pile, by OASYS) has been used and the applied moment at the pile tip that is large enough to mobilize ultimate pressure of the ground profile is taken as the ultimate $M_{R}$ (Schematic for Beam on Non-linear Winkler Foundation shown in Figure 7). Moreover, the $M_{R}$ can be compared with hand calculations from an assumed pressure distribution shown in Figure 6.

For wind farm sites with simple stratigraphy of the soil layers, $M_{R}$ can be checked against the pressure distributions provided by Brom's 1964 method (see distribution in $6(b, f)$ ) where the soil has similar ground profile across the depth. In the analysis, the pile is substituted with a beam element of linear elastic material (no plastic hinge formation or nonlinearity) which means the calculated $M_{R}$ values are due to the failure of the soil. Consequently, the yield and plastic moments can be computed separately and compared to $M_{R}$.
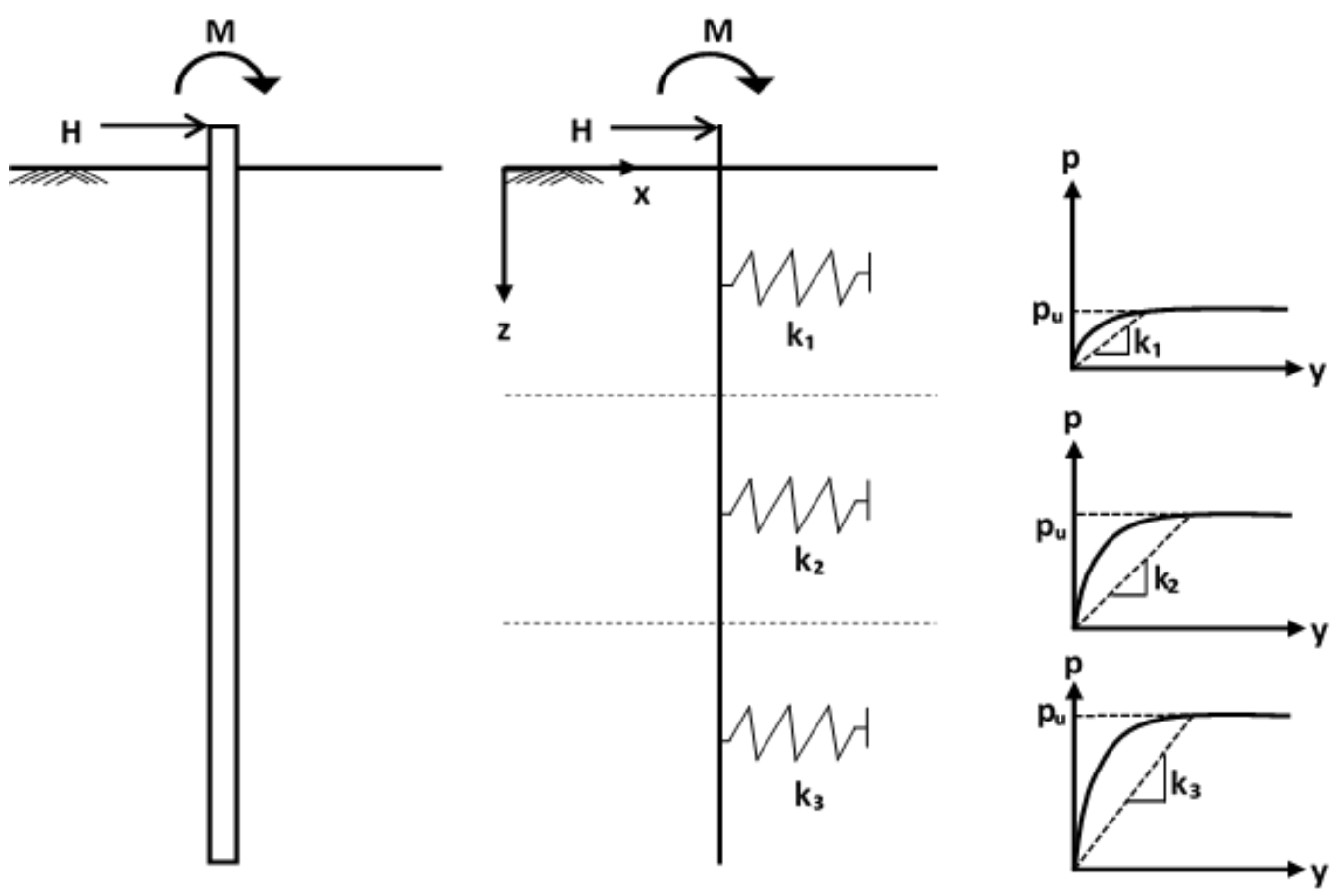

Figure 7: Beam on non-linear Winkler foundation

\subsection{Current available methods for estimating Long Term Tilt}

There are numerous research published on the effect of cyclic loads on monopiles based on full-scale tests, scaled model tests, element testing, and finite element methods. The objective of this section is to provide a brief overview studies on long term tilt of monopiles and summarize the main conclusions and driving parameters. As the mechanism of this phenomenon is complex, disagreements in results are evident in literature and a research gap has been identified in order to assist in the design and interpretation of future tests.

\subsection{Full scale tests}

(Long \& Vanneste, 1994) performed 34 full-scale lateral load tests in sands and studied the effect of load ratio $\left(\mathrm{M}_{\min } / \mathrm{M}_{\max }\right)$, installation parameter, and the effect of soil density on the modulus of reaction, which is a measure of how much a pile deforms under cyclic loads. The study also spanned across different pile sizes covering both rigid piles and 
flexible piles. Based on the test results, degradation factors for calculating soil resistance were derived which can finally be used to produce adjusted non-linear p-y curves as shown in Eq.16-17.

$$
\begin{aligned}
& \mathrm{p}_{\mathrm{N}}=\mathrm{p}_{1} \times \mathrm{N}^{-0.4 \mathrm{t}} \\
& \mathrm{y}_{\mathrm{N}}=\mathrm{y}_{1} \times \mathrm{N}^{0.6 \mathrm{t}}
\end{aligned}
$$

where $\mathrm{N}$ is the number of loading cycles and $\mathrm{t}$ is the degradation parameter as shown in Eq. 18.

$$
\mathrm{t}=0.17 \times \mathrm{F}_{\mathrm{L}} \times \mathrm{F}_{\mathrm{I}} \times \mathrm{F}_{\mathrm{D}}
$$

where $F_{L}$ is dependent on the cyclic load ratio, $F_{I}$ is dependent on the installation method (ranges from 0.9-1.4) and $F_{D}$ is dependent on the soil density (ranges from 0.8-1.1).

The value of $F_{L}$ was recommended to be 1.0 for one-way loading $\left(M_{\min } / M_{\max }=0\right)$ and 0.2 for two-way loading $\left(M_{\min } / M_{\max }=-\right.$ 1). Hence, it may be concluded that the main degradation parameter is the load ratio where one-way loading results in a higher degradation factor than two-way loading. It is important however to mention that these tests were performed up to 50 loading cycles which is significantly smaller than the number of cycles experienced by a typical OWT. Similarly, (Lin \& Liao, 1999) derived degradation parameters from 26-full scale tests for both slender and rigid piles. The degradation parameter is dependent on the load ratio, installation method, and soil density. The logarithmic strain accumulation can be computed using Eq.19-20

$\varepsilon_{\mathrm{N}}=\varepsilon_{1} \times(1+\mathrm{t} \cdot \ln (\mathrm{N}))$

where the degradation parameter $\mathrm{t}$ is calculated using Eq.20

$\mathrm{t}=0.032 \times \mathrm{L}_{\mathrm{P}} \times \sqrt[5]{\frac{\mathrm{n}_{\mathrm{h}}}{\mathrm{E}_{\mathrm{p}} \mathrm{I}_{\mathrm{P}}}} \times \mathrm{F}_{\mathrm{L}} \times \mathrm{F}_{\mathrm{I}} \times \mathrm{F}_{\mathrm{D}}$

where $n_{h}$ is the coefficient of subgrade reaction of the ground and Eplp is the stiffness of the pile

The load ratio degradation parameter $F_{L}$ for one-way loading $\left(M_{\min } / M_{\max }=0\right)$, given to be 1.0 , was also higher than that for symmetric two-way loading $\left(M_{\min } / M_{\max }=-1\right)$, given to be 0.09 . The number of cycles was 50 and the authors stated that caution should be exercised in applying the reduction parameter for applications with more than 50 cycles

\subsection{Scaled model tests}

Recently, scaled model tests have been common practice to study the response of monopiles under larger number of loading cycles. The effect of load ratio $\left(\mathrm{M}_{\min } / \mathrm{M}_{\max }\right)$ at a single or multiple direction has been previously addressed in literature. For instance, (Leblanc, et al., 2010) performed scaled model tests on rigid piles in dry sands of different relative densities. The tests were performed up to 60,000 cycles and under one-way and two-way loads. Based on the results, formulations were provided to predict long term rotation accumulation taking into account scaling between the tests and prototypes as shown in Eq 21.

$\frac{\theta_{\mathrm{N}}-\theta_{1}}{\theta_{\mathrm{S}}}=\mathrm{T}_{\mathrm{b}} \times \mathrm{T}_{\mathrm{C}} \times \mathrm{N}^{0.31}$

where $T_{b}$ is a factor dependent on the intensity of the load $\left(M_{\max } / M_{R}\right)$ and the relative density, and $T_{c}$ is a factor that depends on the load direction $\left(M_{\min } / M_{\max }\right.$ ). It was then concluded that two-way loads (of about $M_{\min } / M_{\max }=-0.6$ ), resulted in higher rotation accumulation of the pile head. (Rudolph, et al., 2014) studied the effect of multi-directionality under one-way loads in centrifuge tests in sand. The study concluded that multi-directional one-way loads increased the accumulation of displacements. (Nanda, et al., 2017) performed scaled model tests for monopiles in sand for loading up to 1000 cycles. The experimental setup contained a gearbox that changed the directionality (changing the load application angle) of both one-way and two-way cyclic loads. The results showed that both multi-directional as well as uni-directional one-way cyclic loads produced a higher horizontal displacement of the monopile head. It is also important to note that multi-directional loads in both cases resulted in higher horizontal deformations. 


\subsection{Design standards and Finite Element method}

From a design point of view, API and DNV codes recommended introducing reduction factors to p-y curves recommended. However, these formulations do not take into account the number of loading cycles and the loading ratio. Moreover, these formulations are empirical and are based on a limited number of tests performed on slender flexible piles. Based on cyclic triaxial tests and Finite Element Modelling, (Achmus, et al., 2009) presented a method to estimate long term tilt and presented design charts as a function of loading cycles. However, the analysis seems to focus on one-way loading. There are also recent efforts to modify $p$-y curves to incorporate the number of loading cycles such as the work by (Erbrich, et al., 2010).

Judging from the above, it is evident that there is a disagreement in the literature on whether one-way or two-way loading is more detrimental. This is more clearly shown by the summary provided in Table 3 . The differences in results might be due to multiple reasons which include the size and scale of each test, number of loading cycles, the rate (frequency) and amplitude of loading, installation method. Furthermore, the model testing setup are either extremely one-way or extreme two-way whereas in reality loading scenarios are a range as discussed in Section 2.1. The above gap in literature calls for a need to clarify the direction of the loading and practical values of $M_{\max } / M_{R}$. This work presented will assist in the design of future experimental frameworks that are specific to OWT applications.

Table 3: Summary of section 4

\begin{tabular}{|l|l|l|l|}
\hline Reference & Test type & Effect of Loading Profile $\mathrm{M}_{\min } / \mathrm{M}_{\max }$ & Other comments \\
\hline $\begin{array}{l}\text { (Long \&anneste, } \\
\text { 1994) }\end{array}$ & Full scale & $\begin{array}{l}\text { One-way loading results in a higher } \\
\text { degradation parameter to the p-y } \\
\text { formulation. Therefore, more tilt is } \\
\text { expected under one-way cyclic loading. }\end{array}$ & $\begin{array}{l}\text { Loading cycles were far far less than what is } \\
\text { to be expected to be experienced by an OWT }\end{array}$ \\
\hline $\begin{array}{l}\text { (Lin \& Liao, } \\
\text { 1999) }\end{array}$ & Full scale & $\begin{array}{l}\text { One-way loading results in a higher } \\
\text { degradation parameter to the cyclic } \\
\text { strain (displacement) }\end{array}$ & $\begin{array}{l}\text { Loading cycles were far less than what is to } \\
\text { be expected to be experienced by an OWT }\end{array}$ \\
\hline $\begin{array}{l}\text { (Leblanc, et } \\
\text { al., 2010) }\end{array}$ & Small scale & $\begin{array}{l}\text { Partial two-way loading resulted in } \\
\text { higher rotation accumulation of the pile }\end{array}$ & $\begin{array}{l}\text { Multidirectional one-way loads resulted in } \\
\text { al., 2014) }\end{array}$ \\
\hline $\begin{array}{l}\text { Rudolph, et } \\
\text { (Nanda, et } \\
\text { al., 2017) }\end{array}$ & Sentrifuge & $\begin{array}{l}\text { Small scale } \\
\text { single direction one-way load }\end{array}$ \\
\hline $\begin{array}{l}\text { Multi-directional as well as } \\
\text { unidirectional one-way loads produced } \\
\text { higher horizontal displacement than } \\
\text { two-way loads }\end{array}$ & $\begin{array}{l}\text { Multidirectional one-way loads resulted in } \\
\text { higher accumulation of displacement than } \\
\text { single direction one-way load. Similar } \\
\text { conclusion to (Rudolph, et al., 2014) }\end{array}$ \\
\hline
\end{tabular}

\subsection{Case Studies and results}

In this section, 15 wind turbines from 12 wind farms are analysed to show the application of the methodology. For all 15 wind turbines, the loads are calculated using the method in Section 2. The input parameters for the load calculation are shown in Table 4

Table 4: Input data for load calculation

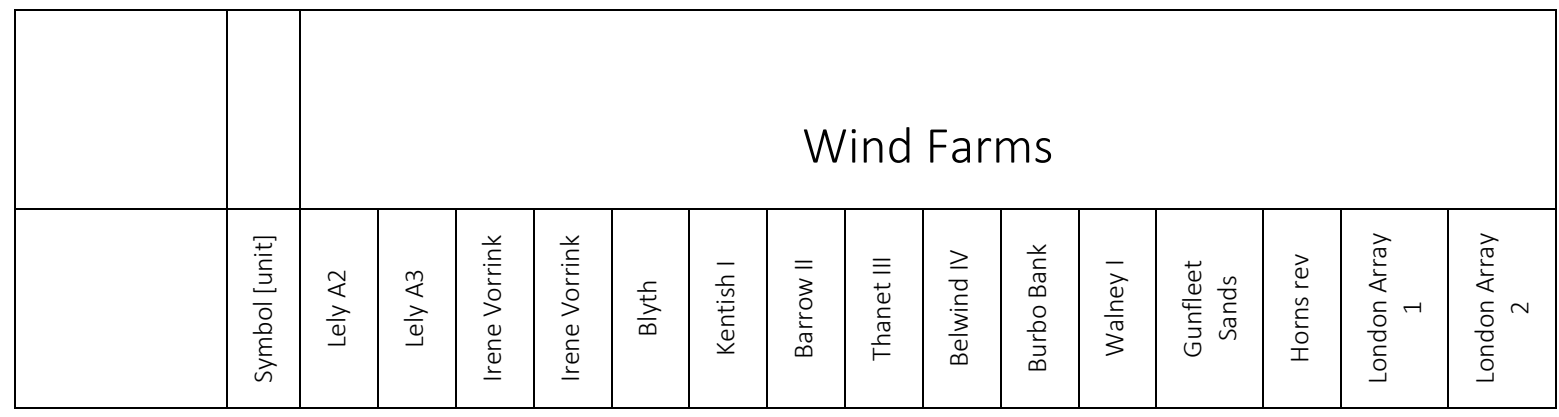




\begin{tabular}{|c|c|c|c|c|c|c|c|c|c|c|c|c|c|c|c|c|}
\hline $\begin{array}{l}\frac{0}{0} \\
\text { o } \\
\stackrel{0}{\tilde{E}} \\
\frac{\pi}{2}\end{array}$ & ' & $\underset{\Xi}{\Xi}$ & $\stackrel{m}{\unlhd}$ & $\stackrel{5}{\geq}$ & $\stackrel{N}{\geq}$ & $\vec{\infty}$ & 岀 & 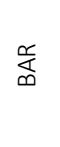 & 吕 & $\vec{\varpi}$ & $\stackrel{\infty}{\infty}$ & $\frac{\vec{k}}{3}$ & 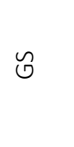 & 吕 & $\vec{s}$ & $\tilde{\Xi}$ \\
\hline 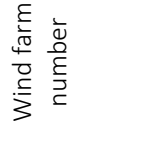 & ' & $r$ & $\sim$ & $m$ & $\nabla$ & 乞 & 6 & $\wedge$ & $\infty$ & $a$ & ㅇ & $\vec{F}$ & ᄀี & $\stackrel{m}{\rightarrow}$ & $\underset{\sim}{\Delta}$ & $\stackrel{\leftrightarrow}{\rightarrow}$ \\
\hline 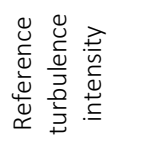 & $\frac{\bar{\varrho}}{\stackrel{g}{g}}$ & $\begin{array}{l}0 \\
\stackrel{\infty}{+}\end{array}$ & 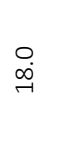 & $\begin{array}{l}\stackrel{0}{\infty} \\
\stackrel{\infty}{\rightarrow}\end{array}$ & $\begin{array}{l}0 \\
\stackrel{\infty}{\rightarrow}\end{array}$ & 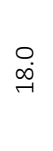 & $\begin{array}{l}\stackrel{0}{\infty} \\
\stackrel{\infty}{\rightarrow}\end{array}$ & $\stackrel{\circ}{\stackrel{\infty}{\sim}}$ & $\underset{\sim}{\stackrel{0}{\sim}}$ & $\begin{array}{l}0 \\
\stackrel{\infty}{\rightarrow}\end{array}$ & $\stackrel{\substack{\infty \\
\sim}}{\sim}$ & $\begin{array}{l}0 \\
\stackrel{\infty}{\sim} \\
\sim\end{array}$ & $\underset{\sim}{\stackrel{\infty}{\sim}}$ & $\begin{array}{l}\stackrel{0}{\infty} \\
\rightarrow\end{array}$ & $\stackrel{\circ}{\stackrel{\infty}{\rightarrow}}$ & $\begin{array}{l}0 \\
\stackrel{\infty}{\sim} \\
\rightarrow\end{array}$ \\
\hline 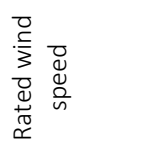 & $\frac{\frac{\bar{n}}{\xi}}{\tilde{x}}$ & $\underset{\sim}{\stackrel{\sim}{\sim}}$ & $\stackrel{\circ}{\underset{J}{f}}$ & 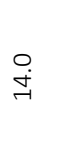 & $\stackrel{\circ}{\underset{f}{f}}$ & $\begin{array}{l}\stackrel{0}{7} \\
\stackrel{-}{n}\end{array}$ & 吕 & 吕 & 吕 & 官 & $\stackrel{\circ}{\stackrel{\sim}{\rightarrow}}$ & $\stackrel{\circ}{\underset{J}{f}}$ & 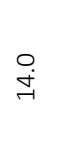 & $\begin{array}{l}\circ \\
\dot{\varphi}\end{array}$ & 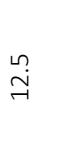 & $\stackrel{\stackrel{L}{7}}{\underset{\exists}{7}}$ \\
\hline 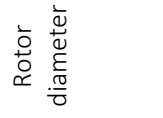 & $\frac{\bar{E}}{\square}$ & 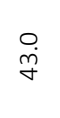 & $\stackrel{\circ}{\dot{\gamma}}$ & 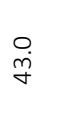 & $\begin{array}{l}\stackrel{一}{\ddot{q}} \\
\dot{m}\end{array}$ & $\begin{array}{l}0 \\
\dot{\theta}\end{array}$ & $\begin{array}{l}\text { \&े } \\
\dot{8}\end{array}$ & $\begin{array}{l}\text { வ் } \\
\text { ه }\end{array}$ & $\begin{array}{l}\text { ஜे } \\
\text { هे }\end{array}$ & $\begin{array}{l}\text { வे } \\
\text { ه }\end{array}$ & 号 & 吕 & $\begin{array}{l}\stackrel{0}{0} \\
\stackrel{0}{0}\end{array}$ & $\begin{array}{l}\circ \\
\stackrel{\infty}{\infty}\end{array}$ & 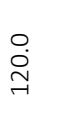 & $\begin{array}{l}\text { ¿ें } \\
\text { đิ }\end{array}$ \\
\hline 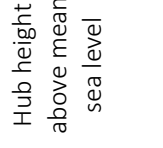 & $\frac{\bar{E}}{\frac{\underline{G}}{\underline{3}}}$ & $\stackrel{n}{\stackrel{n}{\sigma}}$ & 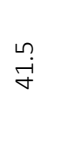 & $\begin{array}{l}\infty \\
\stackrel{\infty}{\infty} \\
\stackrel{\infty}{+}\end{array}$ & $\stackrel{\infty}{\infty} \underset{\sigma}{\infty}$ & $\stackrel{0}{\stackrel{\hat{\sigma}}{0}}$ & 足 & 足 & $\stackrel{\circ}{\circ}$ & $\stackrel{\circ}{i}$ & $\underset{\substack{n \\
\infty}}{\infty}$ & 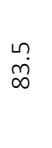 & 贶 & ஓ् & 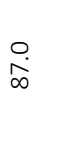 & $\underset{\infty}{\stackrel{0}{\infty}}$ \\
\hline 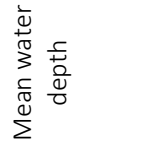 & $\frac{\bar{E}}{n}$ & $\underset{\exists}{\vec{H}}$ & $\stackrel{\vec{r}}{\wedge}$ & กี & $\stackrel{\circ}{\dot{\varphi}}$ & $\stackrel{\infty}{\sim}$ & $\begin{array}{l}\circ \\
\infty\end{array}$ & $\begin{array}{l}\stackrel{0}{\infty} \\
\stackrel{\sim}{\sim}\end{array}$ & 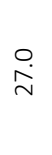 & $\stackrel{\circ}{\stackrel{\sim}{े}}$ & $\begin{array}{l}\circ \\
\infty\end{array}$ & $\stackrel{\leftrightarrow}{\stackrel{\sim}{\sim}}$ & $\stackrel{\sim}{\sim}$ & $\begin{array}{l}\stackrel{0}{\forall} \\
\stackrel{f}{r}\end{array}$ & 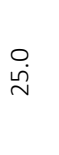 & 吕 \\
\hline 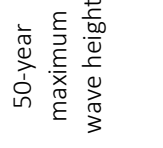 & 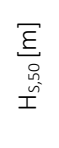 & $\vec{n}$ & $\stackrel{\circ}{\dot{m}}$ & $\tilde{\sim}$ & $\stackrel{\sim n}{\sim}$ & $\stackrel{\varphi}{\sim}$ & $\stackrel{\nabla}{m}$ & $\stackrel{\llcorner}{\sim}$ & 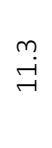 & $\stackrel{\nabla}{\infty}$ & $\stackrel{\nabla}{m}$ & $\stackrel{\circ}{\circ}$ & $\stackrel{m}{\varphi}$ & $\stackrel{\leftrightarrow}{\dot{n}}$ & $\begin{array}{l}\text { n̊ } \\
\stackrel{\theta}{0}\end{array}$ & $\stackrel{\sim}{+}$ \\
\hline 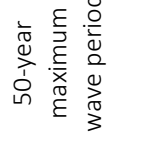 & 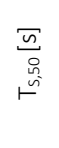 & $\begin{array}{l}0 \\
\infty\end{array}$ & $\vec{b}$ & ஸ̃ & $\underset{\text { in }}{\ln }$ & $\stackrel{\varphi}{\wedge}$ & 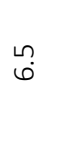 & $\hat{\sigma}$ & $\begin{array}{l}\stackrel{\text { g }}{-} \\
\overrightarrow{-}\end{array}$ & $\begin{array}{l}m \\
\text { o. } \\
\text {. }\end{array}$ & $\stackrel{\sim}{\varphi}$ & $\begin{array}{l}0 \\
\stackrel{0}{\oplus}\end{array}$ & $\stackrel{\sigma}{\infty}$ & $\begin{array}{l}\omega_{\infty}^{0}\end{array}$ & $\begin{array}{l}\stackrel{n}{ت} \\
\underset{-}{-}\end{array}$ & $\stackrel{m}{\sim}$ \\
\hline 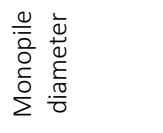 & $\frac{\bar{E}}{a}$ & $\stackrel{\sim}{m}$ & $\hat{m}$ & $\begin{array}{l}\stackrel{\llcorner}{\sim n} \\
\stackrel{\sim}{m}\end{array}$ & 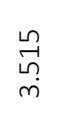 & $\stackrel{\llcorner}{m}$ & $\stackrel{m}{\sim}$ & $\begin{array}{l}\stackrel{\mathscr{n}}{\sim} \\
\stackrel{\sim}{*}\end{array}$ & $\stackrel{\curlyvee}{\stackrel{f}{*}}$ & เn & $\stackrel{\sim}{\dot{\sigma}}$ & 6 & เn & $\nabla$ & సં & $\stackrel{\sim}{\dot{f}}$ \\
\hline 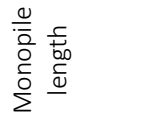 & $\frac{\bar{\xi}}{a}$ & $\begin{array}{l}\stackrel{r}{y} \\
\underset{r}{r}\end{array}$ & $\begin{array}{l}\text { ̊n } \\
\text { }\end{array}$ & $\begin{array}{l}\stackrel{\varphi}{\sim} \\
\stackrel{\sim}{\sim}\end{array}$ & $\begin{array}{l}\dot{0} \\
\stackrel{d}{\sim}\end{array}$ & $\stackrel{\sim}{\sim}$ & 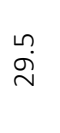 & q & ○ & $\stackrel{\stackrel{n}{m}}{n}$ & $\stackrel{\nabla}{\sim}$ & 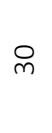 & $\stackrel{\infty}{m}$ & $\stackrel{\llcorner}{\sim}$ & $\stackrel{m}{\text { m }}$ & $\stackrel{m}{m}$ \\
\hline 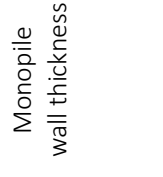 & $\frac{\bar{E}}{\stackrel{E}{\omega}}$ & 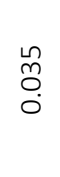 & $\begin{array}{l}\stackrel{\omega}{n} \\
\stackrel{0}{0}\end{array}$ & 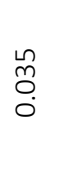 & $\begin{array}{l}\stackrel{\sim}{n} \\
\stackrel{0}{0} \\
0\end{array}$ & $\begin{array}{l}0 \\
\text { On } \\
\text { O. }\end{array}$ & $\begin{array}{l}\stackrel{\vartheta}{0} \\
\stackrel{0}{0}\end{array}$ & $\begin{array}{l}0 \\
\stackrel{0}{0} \\
0\end{array}$ & $\begin{array}{l}\stackrel{n}{0} \\
\varnothing \\
0 \\
0\end{array}$ & $\begin{array}{l}0 \\
\text { 员 } \\
\text { O. }\end{array}$ & $\begin{array}{l}\stackrel{n}{n} \\
\hat{O} \\
0\end{array}$ & $\begin{array}{l}0 \\
\stackrel{0}{0} \\
0\end{array}$ & $\begin{array}{l}\text { Oे } \\
\text { O. } \\
\text { O. }\end{array}$ & $\begin{array}{l}\text { On } \\
\text { O. } \\
\text {. }\end{array}$ & $\begin{array}{l}n \\
\hat{0} \\
0 \\
0\end{array}$ & $\begin{array}{l}\qquad 0 \\
0 \\
0 \\
0\end{array}$ \\
\hline 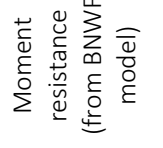 & $\sum_{\substack{E \\
\sum}}^{\xi}$ & $\stackrel{\infty}{\wedge}$ & $\underset{m}{m}$ & ¿্口 & ¿̊̀ & ' & $\stackrel{\stackrel{P}{\sim}}{\sim}$ & 员 & 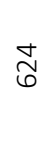 & 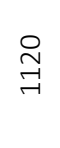 & $\stackrel{\Im}{\forall}$ & $\underset{\exists}{\stackrel{U}{U}}$ & 占 & जे & $\stackrel{n}{\circ}$ & $\stackrel{\circ}{\curvearrowright}$ \\
\hline
\end{tabular}




\begin{tabular}{|c|c|c|c|c|c|c|c|c|c|c|c|c|c|c|c|c|}
\hline 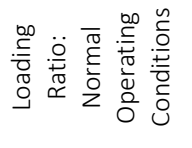 & 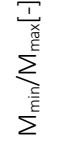 & $\stackrel{\vec{\jmath}}{\stackrel{0}{0}}$ & $\stackrel{\text { In }}{0}$ & 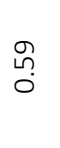 & 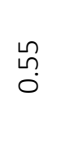 & $\begin{array}{l}0 \\
0 \\
0\end{array}$ & : & 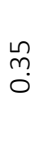 & $\begin{array}{l}\text { ot } \\
\text { Oे }\end{array}$ & 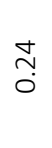 & $\begin{array}{l}\infty \\
\stackrel{\infty}{0} \\
0\end{array}$ & 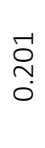 & $\stackrel{\infty}{+}$ & $\stackrel{\text { g }}{\circ}$ & 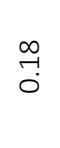 & $\stackrel{n}{0}$ \\
\hline 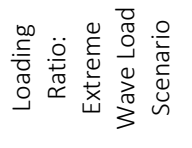 & 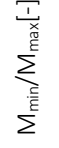 & $\begin{array}{l}\hat{m} \\
\text { ọ }\end{array}$ & $\begin{array}{l}\hat{\sigma} \\
\text { ò } \\
\text { in }\end{array}$ & 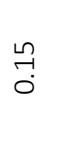 & $\begin{array}{l}\infty \\
0 \\
0\end{array}$ & $\begin{array}{l}\overrightarrow{0} \\
\overrightarrow{0}\end{array}$ & 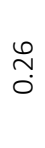 & $\begin{array}{l}\infty \\
\stackrel{0}{\rightarrow} \\
\stackrel{1}{1}\end{array}$ & $\begin{array}{l}\text { f } \\
\text { ị }\end{array}$ & $\begin{array}{l}\vec{m} \\
\stackrel{p}{i}\end{array}$ & $\stackrel{m}{m}$ & 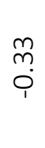 & $\begin{array}{l}8 \\
8 \\
0 \\
0\end{array}$ & $\begin{array}{l}\text { oे } \\
\text {. }\end{array}$ & $\begin{array}{l}\vec{n} \\
m \\
\stackrel{1}{i}\end{array}$ & $\stackrel{\mathscr{N}}{0}$ \\
\hline 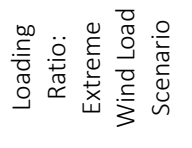 & 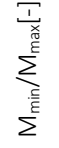 & $\begin{array}{l}\text { ने } \\
\text { ị }\end{array}$ & $\begin{array}{l}\mathscr{8} \\
\varnothing \\
0\end{array}$ & $\begin{array}{l}\stackrel{ }{-} \\
\stackrel{-}{0}\end{array}$ & $\begin{array}{l}\text { No } \\
\text { Oִ } \\
0\end{array}$ & $\begin{array}{l}\stackrel{\infty}{n} \\
\stackrel{0}{0}\end{array}$ & $\begin{array}{l}\hat{\sigma} \\
\text { - } \\
\text { - }\end{array}$ & $\begin{array}{l}\tilde{N} \\
0 \\
0 \\
0\end{array}$ & $\begin{array}{l}\stackrel{N}{N} \\
\stackrel{1}{i}\end{array}$ & $\begin{array}{l}0 \\
\stackrel{7}{7} \\
\stackrel{1}{1}\end{array}$ & $\begin{array}{l}\stackrel{+}{\stackrel{D}{0}} \\
\text { }\end{array}$ & 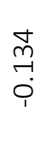 & $\begin{array}{l}\hat{\theta} \\
0 \\
0\end{array}$ & $\begin{array}{l}\infty \\
\stackrel{0}{\circ}\end{array}$ & $\begin{array}{l}\stackrel{\text { fo }}{-} \\
\stackrel{9}{i}\end{array}$ & $\begin{array}{l}\sigma \\
\stackrel{0}{0} \\
\stackrel{0}{0}\end{array}$ \\
\hline
\end{tabular}

Note: Ground profiles for these wind farms are shown in Appendix A

Based on the information provided in Table 4, the loading time history was computed for the wind farms presented for the 3 load cases as shown in Section 2.1. For instance, taking the case of London Array 1, the time history of load case 1 shown in Table 1 which has the Normal Turbulence Model (NTM) at the rated wind speed for the wind load and 1Year Extreme Sea State (ESS). Figure 8 shows the superimposed wave loads from the 1-year ESS and wind load from the NTM forming up the loads for the normal operational conditions load case. $\mathrm{M}_{\min } / \mathrm{M}_{\max }$ can then be taken as the ratio of the highest peaks as shown in Figure 8. For this case $M_{\min } / M_{\max }=24 / 131=0.18$, which is indicative of one-way loading conditions

\section{London Array 1}

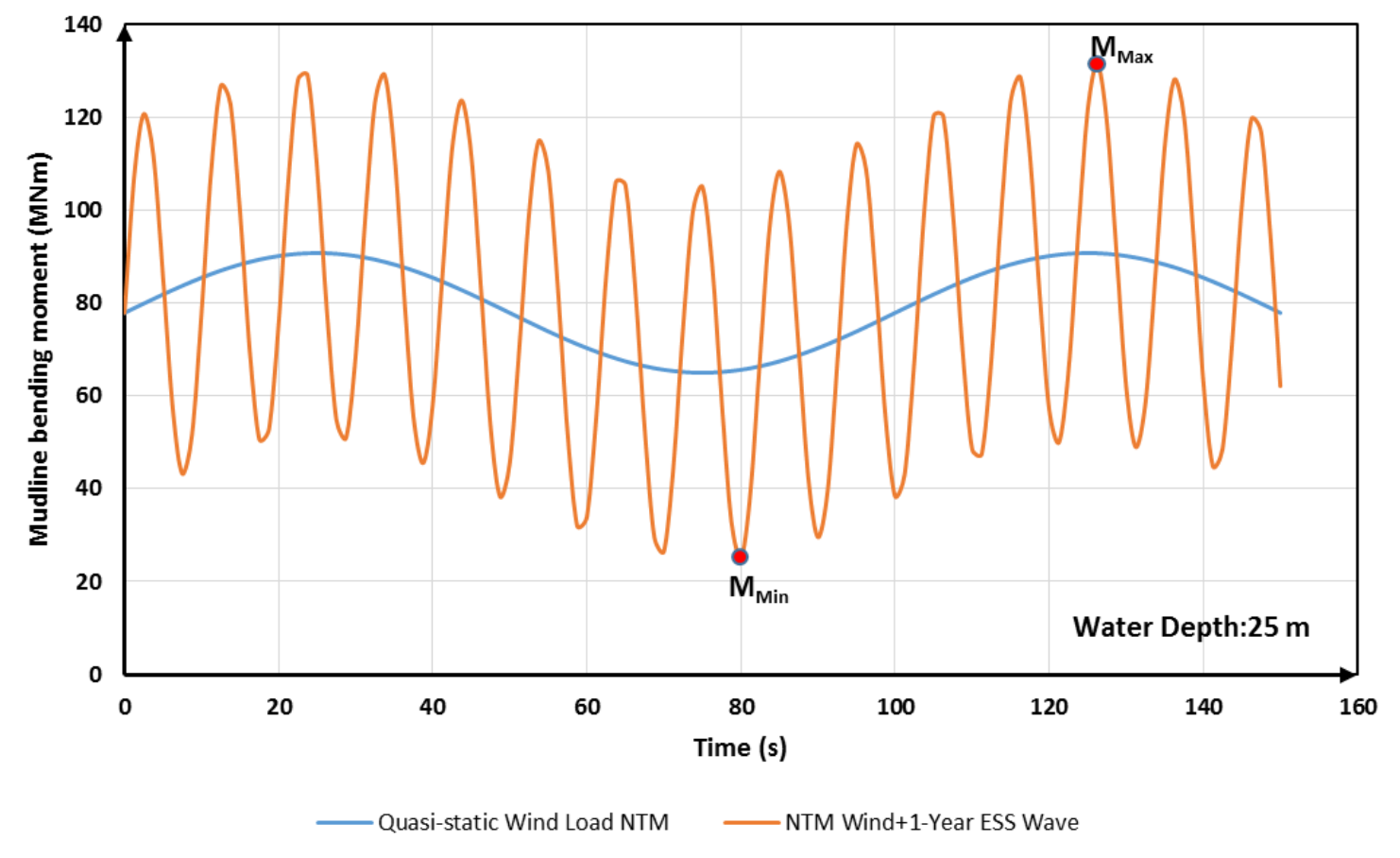

Figure 8: Time history for normal operating conditions for London Array 1

Similarly, if load case 2 (ETM model for wind and 50-year EWH for wave) is taken for the Walney wind turbine, the applied cyclic moment shown in Figure 9 is achieved. It may be observed that in this case $M_{\min } / M_{\max }=-68 / 200=-0.34$ which is indicative of two-way loading. Primarily, this means the applied loads can either be one-way or two-way depending on the loading scenario selected, turbine size and water depth. The next section discusses results from the remaining wind farms and draws conclusions on the direction of loading profiles. 


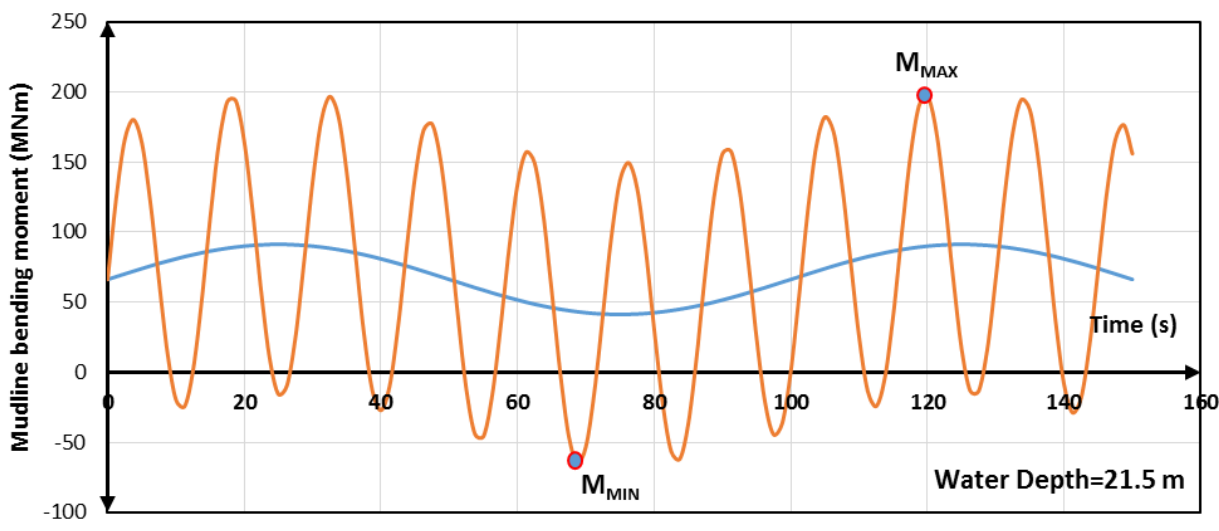

_uasi-static Wind Load (ETM) _ ETM Wind+50-Year EWH Wave

Figure 9: Time history for Extreme wave load scenario for Walney

\section{1 $\mathrm{M}_{\min } / \mathrm{M}_{\max }$ for operating wind turbines}

Results for the cases presented in Table 4 were processed in terms of turbine size and water depth for all load cases. For instance, Figure 10 shows the results for $3.0 \mathrm{MW}$ and $3.6 \mathrm{MW}$ wind turbines. It is interesting to note that both 3.0 and $3.6 \mathrm{MW}$ turbines exhibited one-way loading for Normal Operational Conditions even at higher water depths. $\mathrm{M}_{\min } / \mathrm{M}_{\max }$ shifts from higher values of 0.6 at shallow water depths of about $10 \mathrm{~m}$ to low values ( 0 to 0.1 ) at higher water depths of $25 \mathrm{~m}$, which means under normal conditions, currently installed wind turbines may not experience twoloading. Please note that the turbine code names are provided in Table 4.

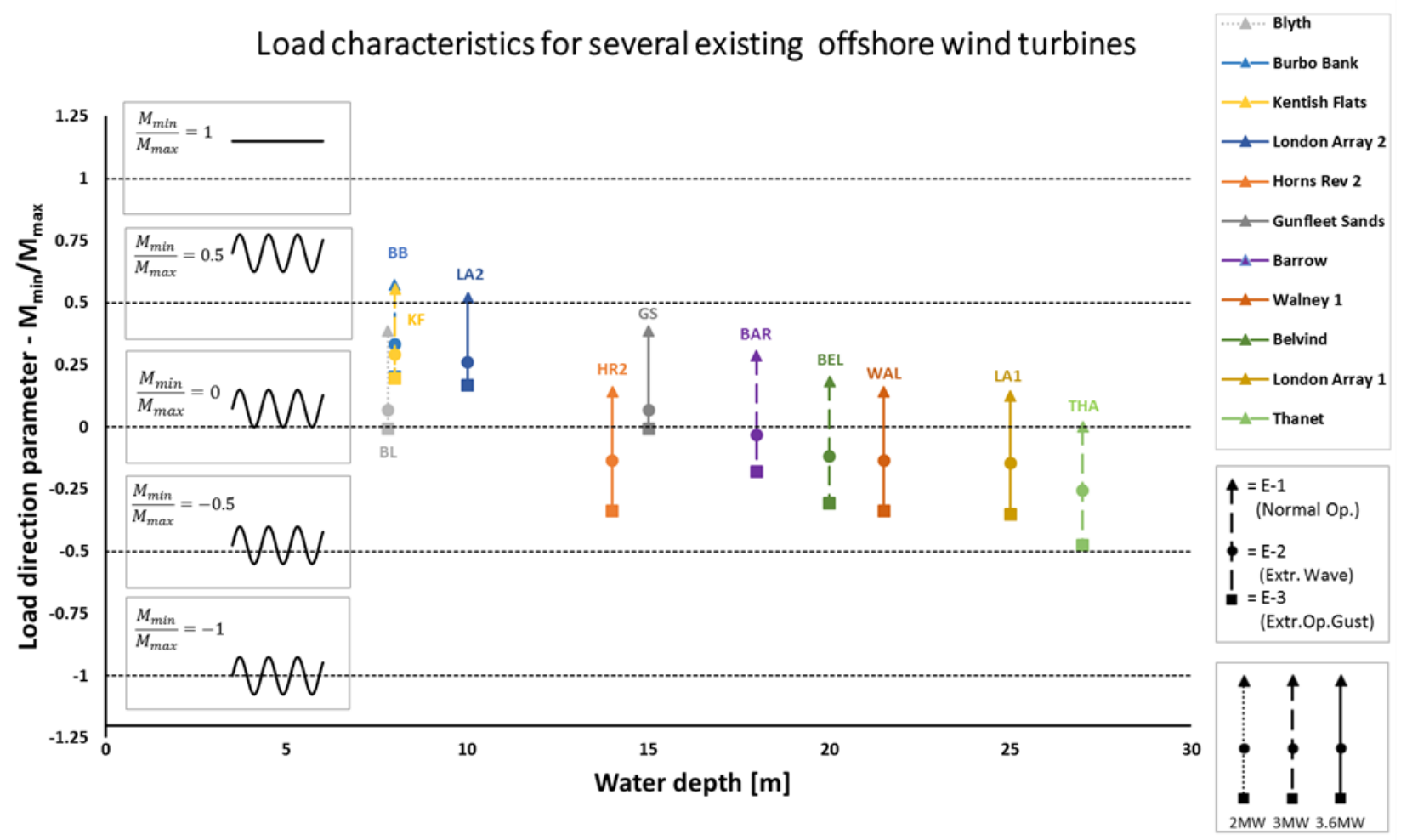

Figure 10: $\mathrm{M}_{\min } / \mathrm{M}_{\max }$ for different load cases for 3.0MW and 3.6MW Wind turbines

This is because under normal conditions for the same wind turbine rotor diameter, the wind load varies slightly depending on the rated wind speed. As the water depth increases, the cyclic wave loads increase in magnitude, and thus increasing the contribution of wave loads to the total cyclic load. This results in lower $M_{\min }$ values relative to $M_{\max }$ It is only when extreme wave or wind loading scenarios are considered that negative values of $M_{\min } / M_{\max }$ start to arise at medium water depths and above (15m+). The lowest $\mathrm{M}_{\min } / \mathrm{M}_{\max }$ (of about -0.5) occurs due to extreme wave scenarios 
at higher water depths. Considering that the probability of such occurrences are low ( 50 year return period which takes the maximum wave height) and the time duration of a few hours for such events is relatively low compared to the service life of an OWT (25-30 years), it is safe to assume that current windfarm developments in Europe are mostly under the action of one-way loading. Consequently, any future studies on similar sizes must consider $\mathrm{M}_{\min } / \mathrm{M}_{\max }$ values of 0 to 0.5 depending on the required water depth rather than extreme values ranging from -1 to 1 . It may be reminded that wave loads consider the summation of the maximum drag and inertia values which means the contribution of the waves are lower in reality which will result in even higher $\mathrm{M}_{\min } / \mathrm{M}_{\max }$ values. A more realistic event would be having oneway loading for the majority of test loading cycles followed by a sudden shift to two-way loading simulating the occurrence of an extreme wind or wave scenario.

\subsection{Predicting $\mathrm{M}_{\min } / \mathrm{M}_{\max }$ for 8MW and $10 \mathrm{MW}$ wind turbines.}

The methodology presented above was applied to larger size wind turbines. The turbine sizes selected for this study were the Vestas V164 8.0 MW wind turbine and the DTU reference $10 \mathrm{MW}$ wind turbine described in (Desmond, et al., 2016). The wind turbines were placed in different windfarm sites shown in Table 4 and accordingly the loading ratio was computed. For instance, Figures 1-2 in Appendix B show the Normal Operational Conditions for the $10 \mathrm{MW}$ wind turbine in shallow and deep waters. Figure 11 shows the summarized $M_{\min } / M_{\max }$ values for the three load cases. Similar trends appear to those of the smaller turbines in Figure 10. The difference lies in deeper water where $M_{\min } / M_{\max }$ for larger turbines are higher than the ones of smaller turbines.

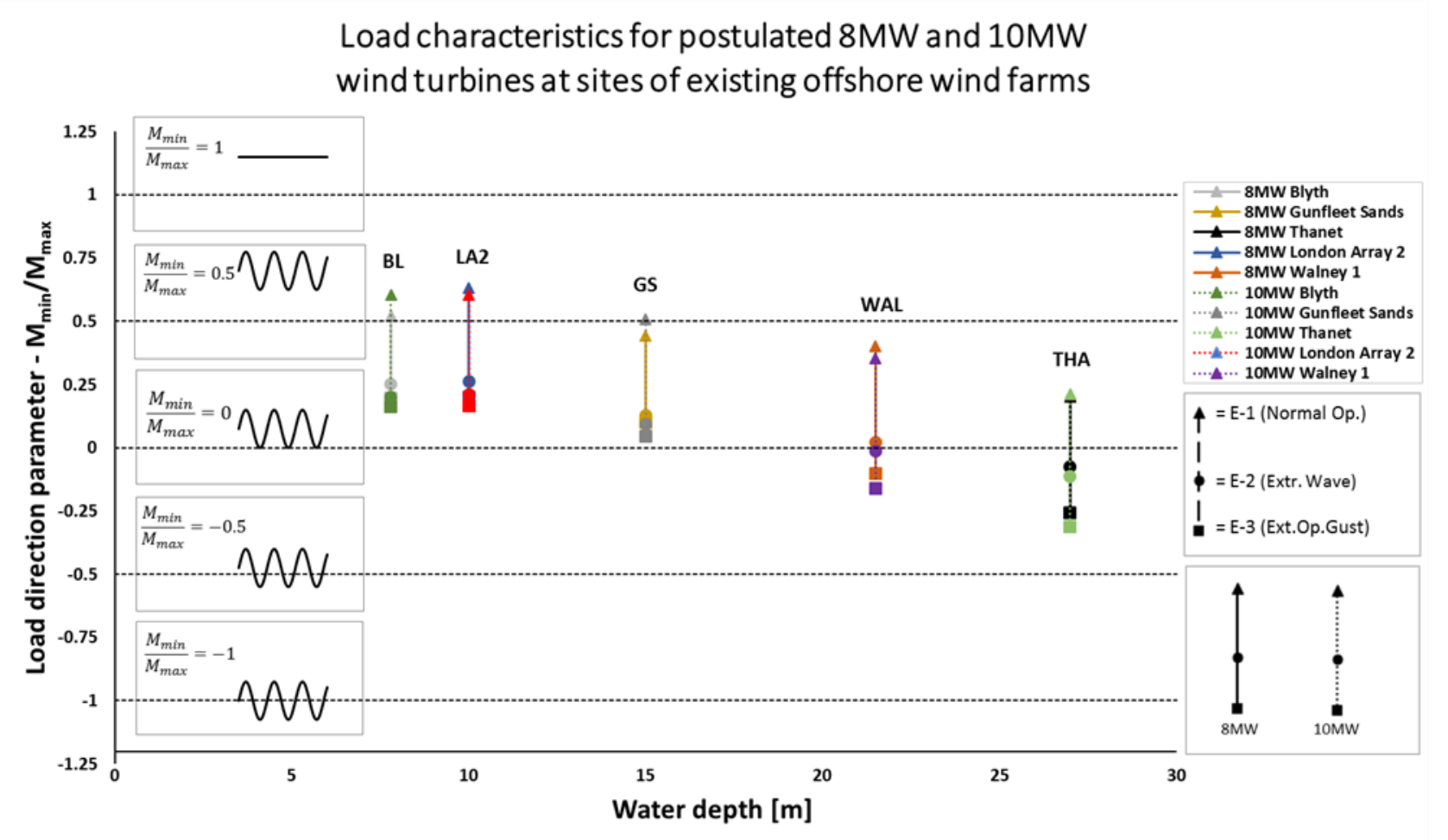

Figure 11: $\mathrm{M}_{\min } / \mathrm{M}_{\max }$ for different load cases for 8.0MW and 10MW Wind turbines

To put the results in perspective, results from all wind turbine sizes are plotted for normal operational conditions as shown in Figure 12. What can be noted from the figure is that for lower water depths, the turbine size does not seem to greatly influence the value of $\mathrm{M}_{\min } / \mathrm{M}_{\max }$ as the wind load has the highest contribution to the total load. At deeper waters, wave loads start to dominate, however for bigger turbines the wind load is also high (due to the large rotor diameter) which shifts the superimposed load upwards. This can be seen by comparing Figure 1 and Figure 2 in Appendix B. Conclusively it may be predicted that for monopile supported OWTs, which are also likely to be installed in deeper water, $M_{\min } / M_{\max }$ is expected to be in the low positive values 0.2-0.3 which may be described as one-way loaded. 


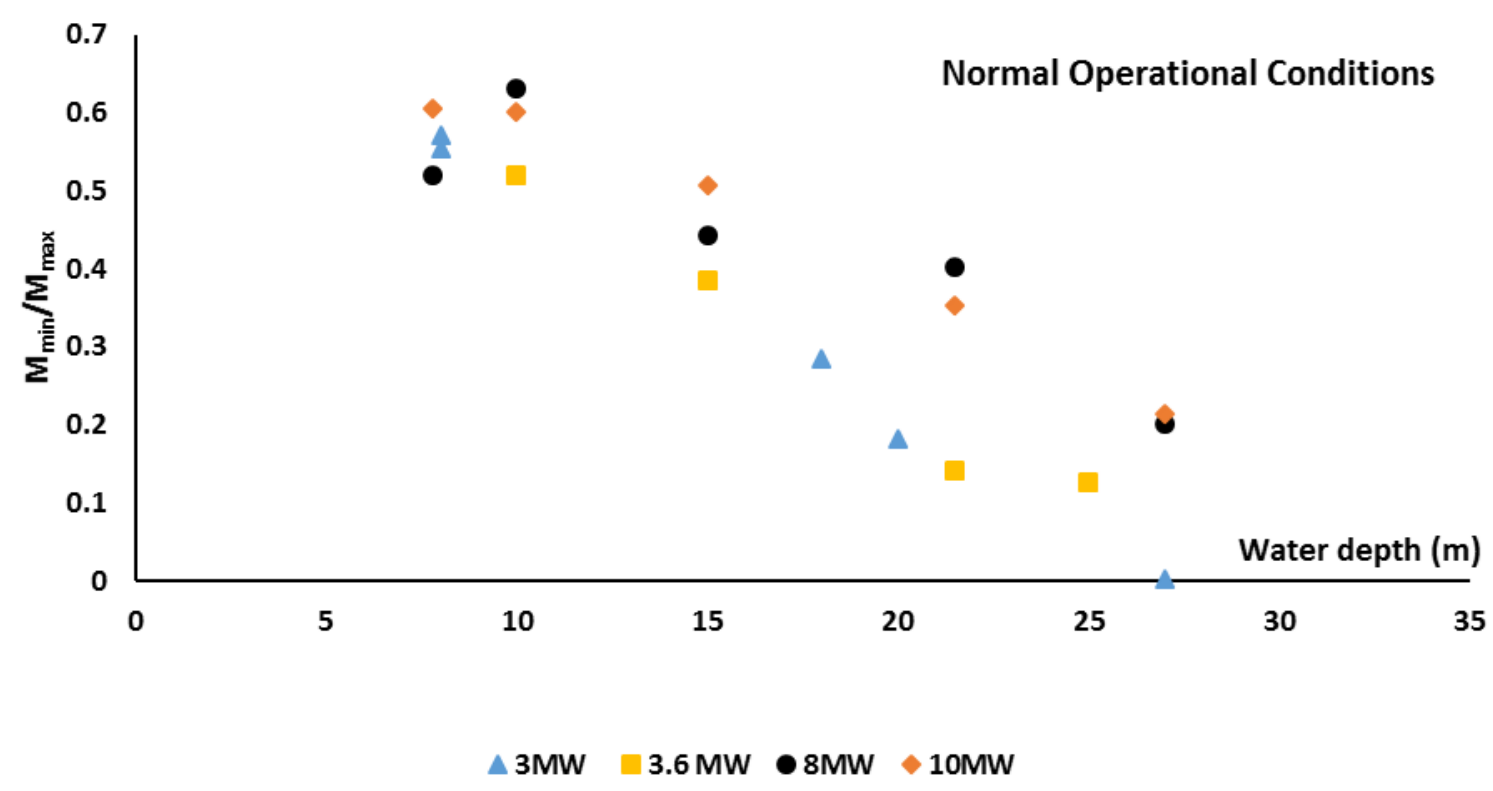

Figure 12: $\mathrm{M}_{\min } / \mathrm{M}_{\max }$ for different load cases for 8.0MW and $10 \mathrm{MW}$ Wind turbines under Normal Operational Conditions

\section{3 $\mathrm{M}_{\max } / \mathrm{MR}_{\mathrm{R}}$ for Existing Wind Farms}

Literature suggests that $M_{\max } / M_{R}$ may also affect the tilt resistance of monopiles. The $M_{R}$ for the case studies in table 4 were estimated using commercial software ALP as explained in Section 3.3. Appendix A contains the estimated ground profiles and soil profiles used in this study. Figure 13 plots $M_{\max } / M_{R}$ for currently operating 3 and $3.6 \mathrm{MW}$ turbines. It seems that the ratio ranges for $10-20 \%$ for most cases and can go up to $40 \%$ for extreme loading cases as shown in Appendix C. Hence, this can also be valuable information when assessing the strains on the surrounding soils when studying long term tilt. Higher strains under undrained conditions may lead to higher stiffness degradation which may lead to higher tilt.

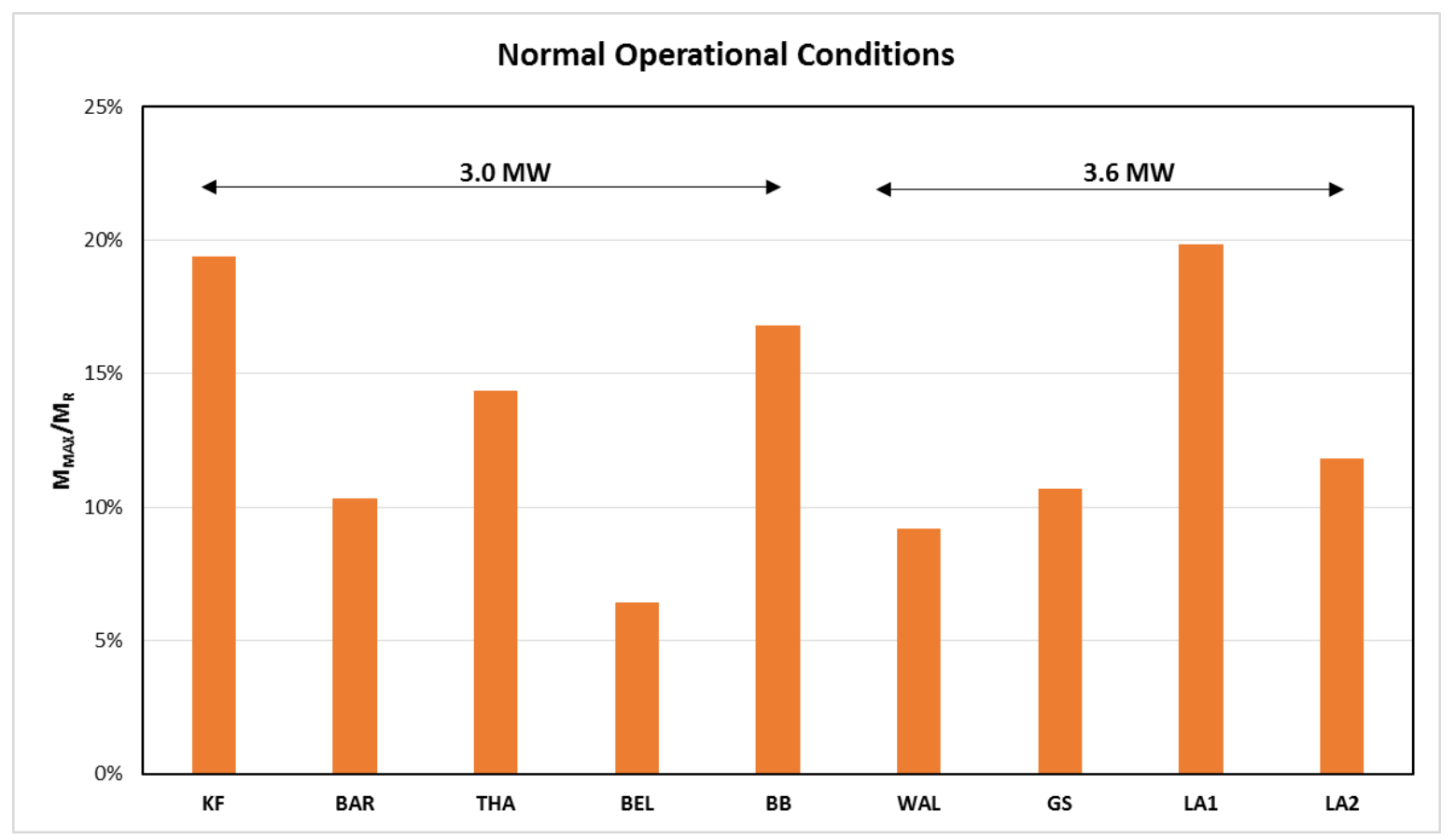

Figure 13: $\mathrm{M}_{\max } / \mathrm{M}_{\mathrm{R}}$ for 3.0 and 3.6MW wind turbines under Normal Operational Conditions

\subsection{Conclusions}

This paper develops a method to predict the cyclic loading profiles on monopile foundations for 15 operating wind farms based on minimum amount of data (i.e. necessary which may not be sufficient for a very detailed analysis). Through a simplified mudline bending moment time history, the cyclic loading ratio i.e. the ratio of the minimum mudline moment 
$\left(M_{\min }\right)$ to the maximum mudline moment $\left(M_{\max }\right)$ is obtained. The data from 15 monopile-supported wind turbines from 12 European wind farms are considered to find the loading pattern. The analysis showed that loads on monopiles are one-way under Normal Operational Conditions. Furthermore, the loading directions can be two-way in extreme wind and wave loading scenarios in deep waters. The ratio of the maximum mudline moment $\left(\mathrm{M}_{\min }\right)$ is compared with the moment of resistance $\left(M_{R}\right)$ of the piles and typical values of $M_{\max } / M_{R}$ are 0.1 to 0.2. for normal operational conditions. These findings can be used to design and plan scaled model tests intended to understand the response of monopiles under cyclic loading for quantifying long-term tilt. 


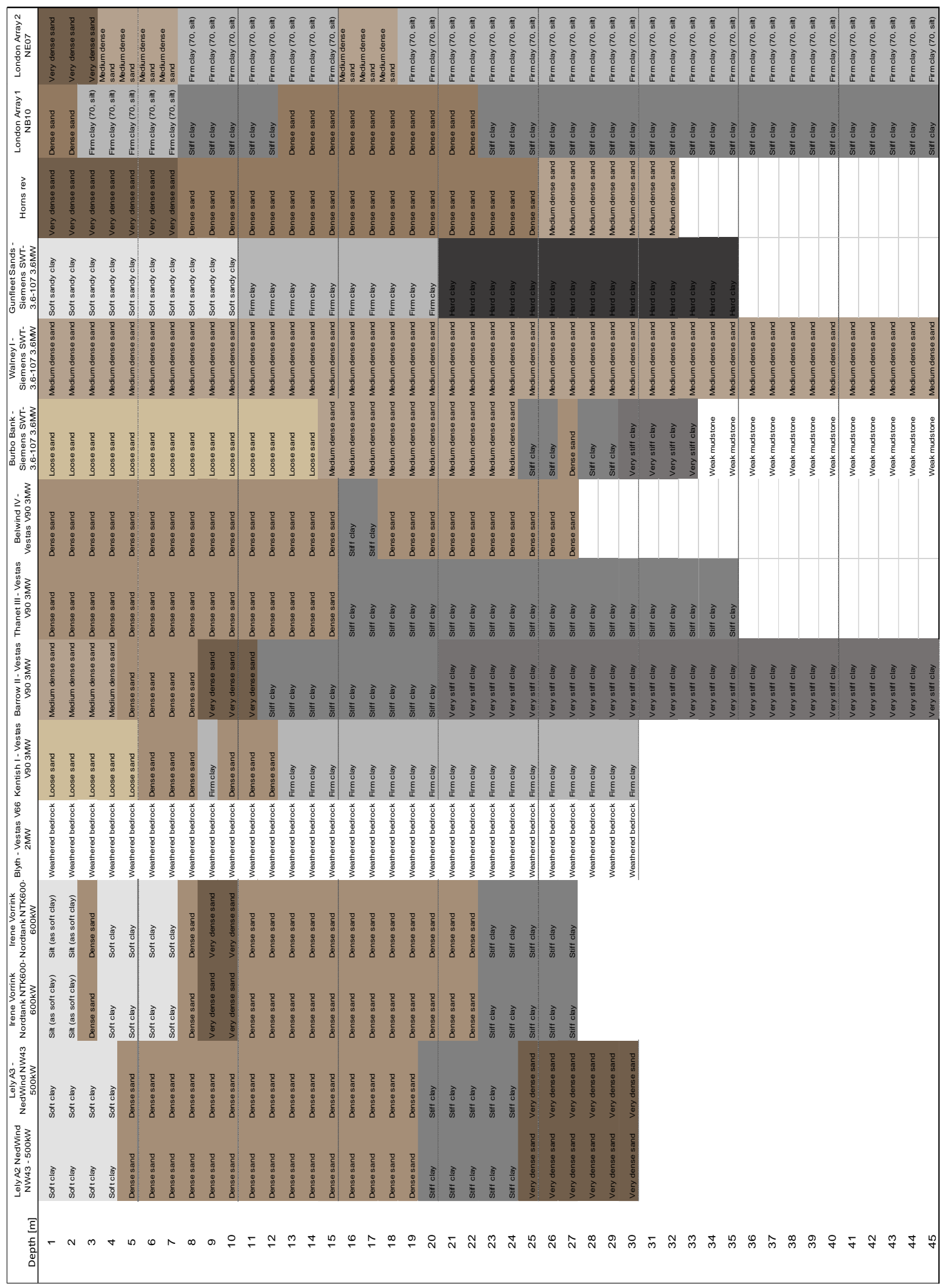


Table A2: Soil parameters assumed for typical sandy soils in p-y analysis.

\begin{tabular}{|l|c|c|c|c|c|}
\hline Sand $p$-y parameters & Very loose & Loose & Medium & Dense & Very dense \\
\hline Friction angle $\left(\phi^{\prime}\right)$ & 28 & 30 & 33 & 38 & 40 \\
\hline Effective unit weight $\left(\gamma^{\prime}\left[\mathrm{kN} / \mathrm{m}^{3}\right]\right)$ & 6 & 7 & 8 & 9 & 10 \\
\hline Relative density $\left(\mathrm{R}_{\mathrm{d}}\right)$ & 15 & 20 & 40 & 60 & 80 \\
\hline Initial stiffness gradient $(\mathrm{k})$ & 3000 & 8000 & 16000 & 30000 & 40000 \\
\hline
\end{tabular}

Table A3: Soil parameters assumed for typical clayey soils in p-y analysis

\begin{tabular}{|l|c|c|c|c|c|}
\hline Clay p-y parameters & Soft & Firm & Stiff & Very stiff & Hard \\
\hline Undrained shear strength $\left(\mathrm{cu}_{\mathrm{u}}\right)$ & 25 & 50 & 100 & 200 & 400 \\
\hline J parameter [-] & 0.25 & 0.25 & 0.25 & 0.25 & 0.25 \\
\hline Strain, 50\% failure stress $\left(\varepsilon_{50}[-]\right)$ & 0.007 & 0.006 & 0.005 & 0.004 & 0.003 \\
\hline Effective unit weight $\left(\gamma^{\prime}\left[\mathrm{kN} / \mathrm{m}^{3}\right]\right)$ & 7 & 8 & 9 & 10 & 12 \\
\hline Young's modulus (Es $[\mathrm{MPa}])$ & 1.25 & 2.5 & 5 & 10 & 20 \\
\hline
\end{tabular}




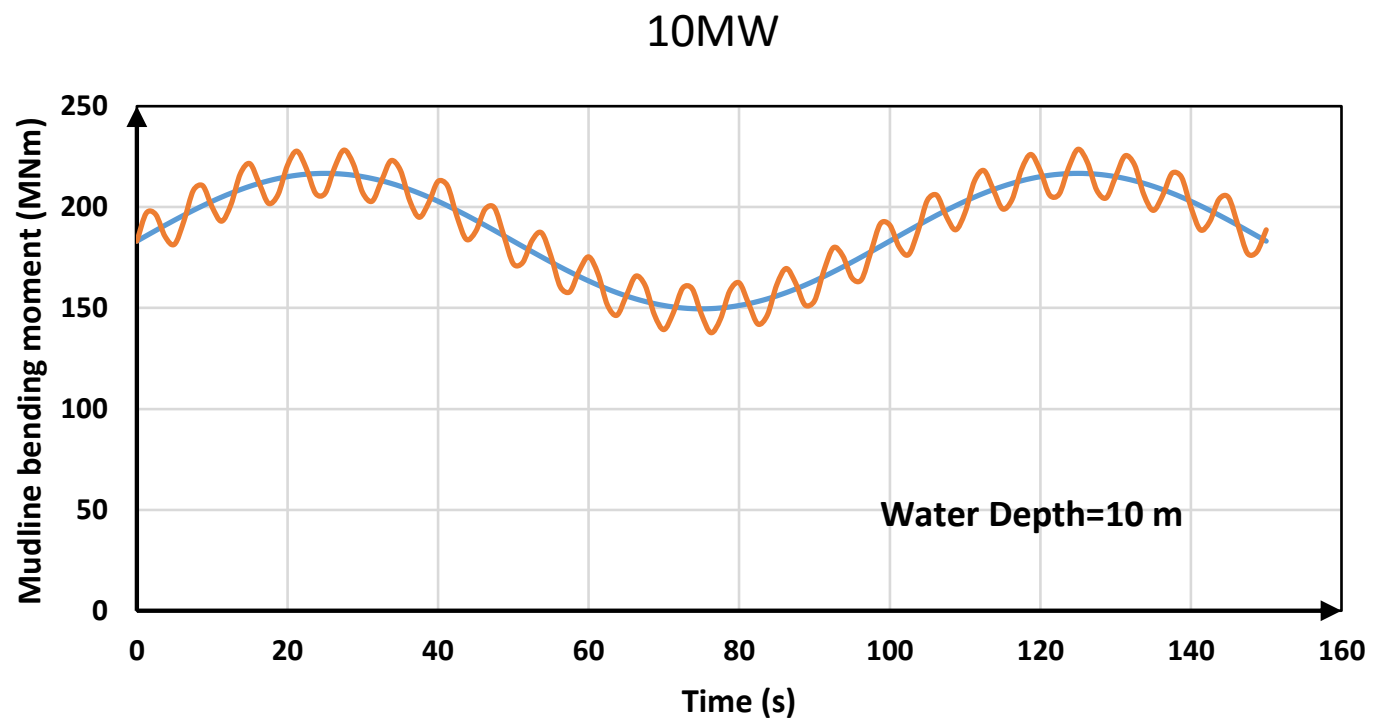

Quasi-static Wind Load NTM _ NTM Wind+1-Year ESS Wave

Figure B1: Normal Operational Conditions loading time history for $10 \mathrm{MW}$ turbine in shallow water depths

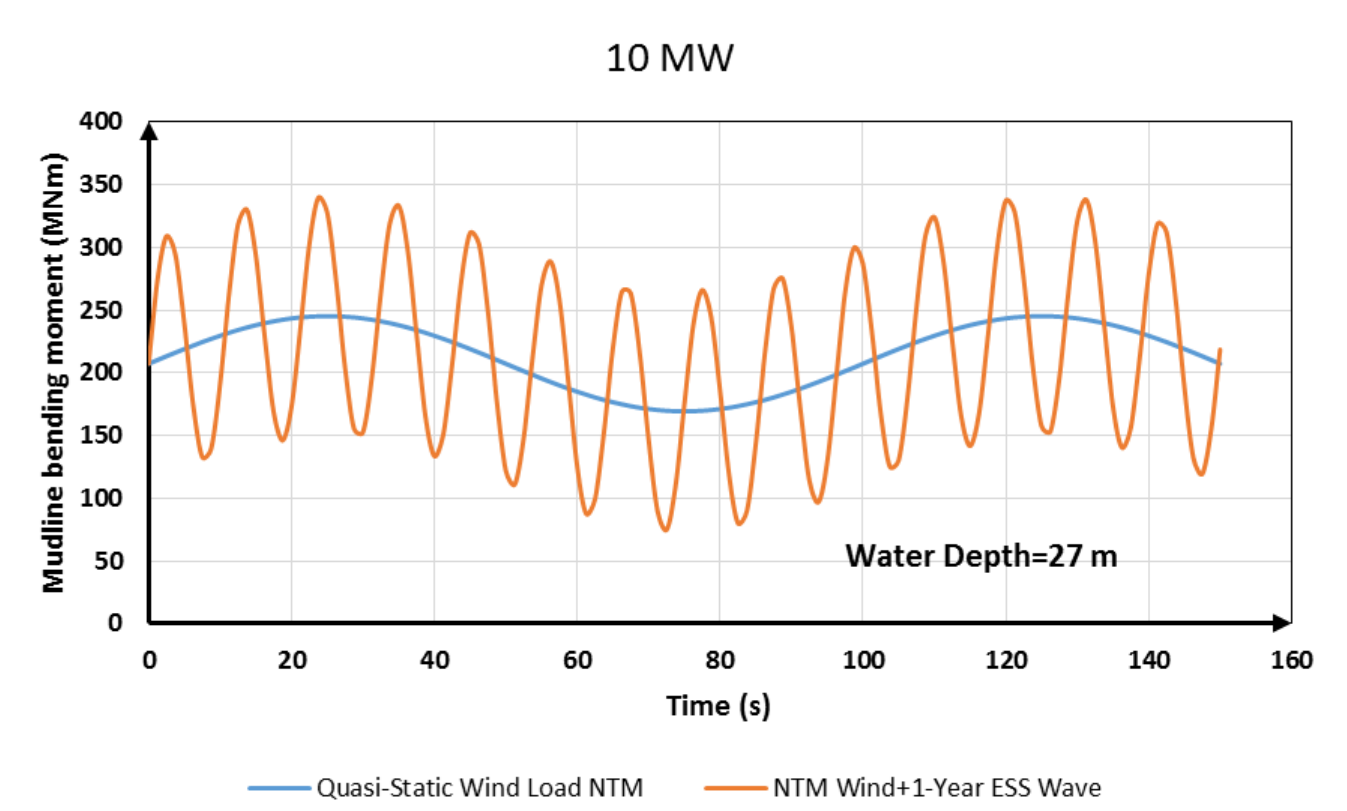

Figure B2: Normal Operational Conditions loading time history for $10 \mathrm{MW}$ turbine in deeper waters 
Appendix C: $M_{\max } / M_{R}$ for extreme wave load scenario

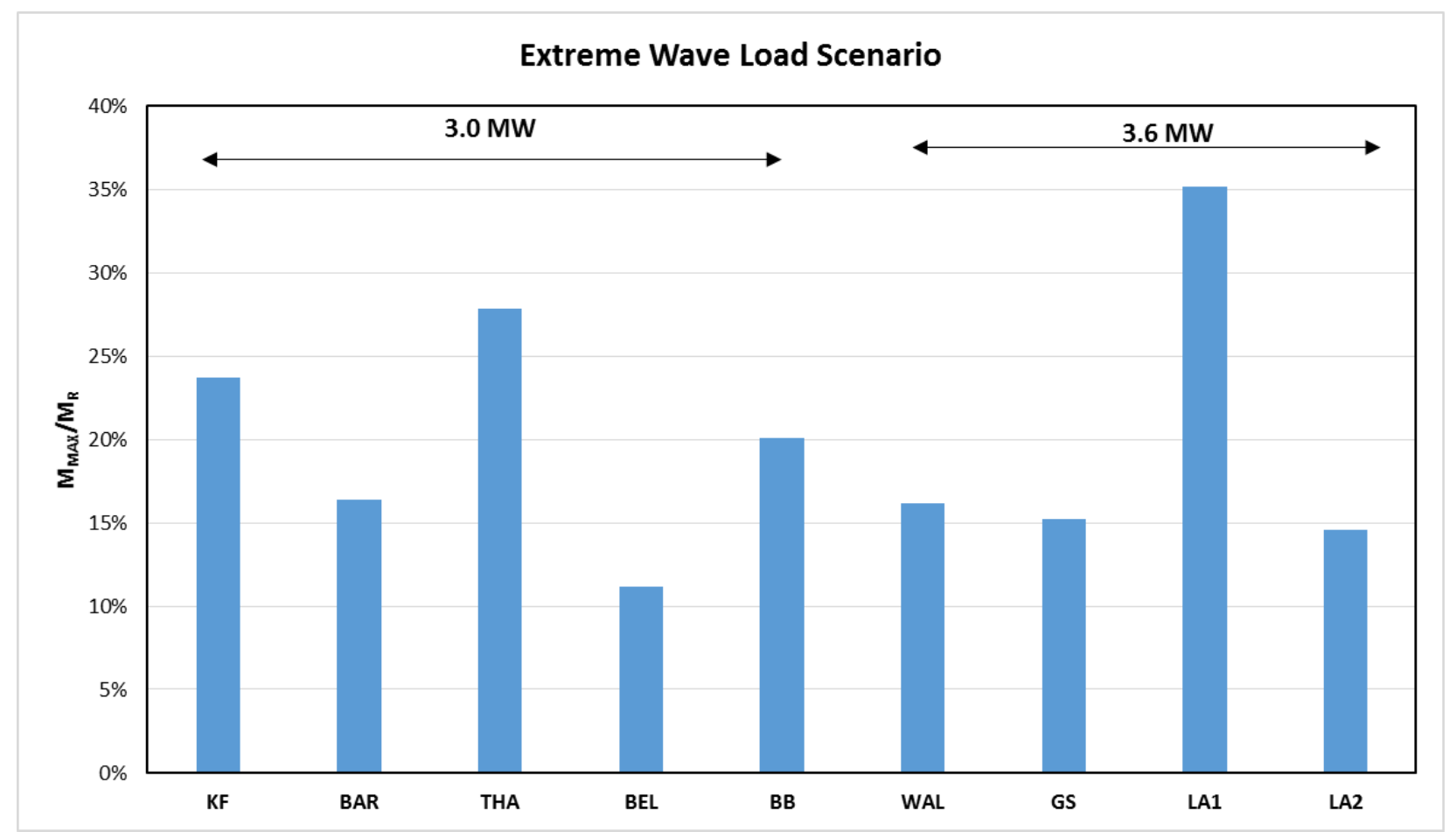

Figure $\mathrm{C} 1: \mathrm{M}_{\max } / \mathrm{M}_{\mathrm{R}}$ for 3.0 and 3.6MW wind turbines under Extreme Wave Loads

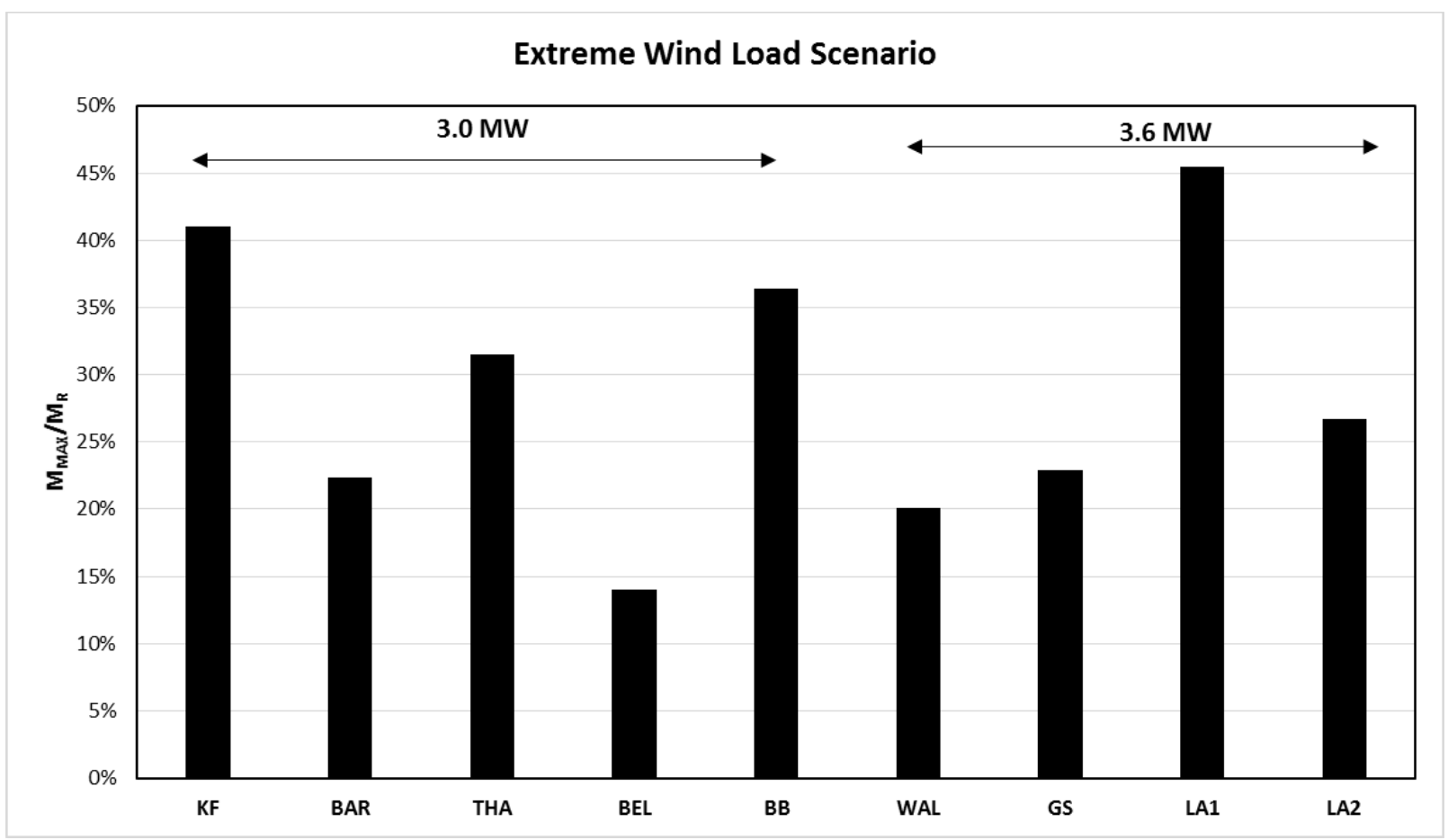

Figure $\mathrm{C} 2: \mathrm{M}_{\max } / \mathrm{M}_{\mathrm{R}}$ for 3.0 and 3.6MW wind turbines under Extreme Wind Loads 


\section{References}

Achmus, M., Kuo, Y. \& Rahman, K., 2009. Behaviour of monopile foundations under cyclic lateral loading. Computers and Geotechnics, 5(36), pp. 725-735.

API, 2007. Reccomended practice for planning, designing and constructing fixed offshore platformsworking stress design. s.I.:s.n.

Arany, L. \& Bhattacharya, S., 2018. Simplified load estimation and sizing of suction anchors for spar buoy type floating offshore wind turbines. Ocean Engineering, Issue 159, pp. 348-357.

Arany, L., Bhattacharya, S., Macdonald, J. \& Hogan, S. J., 2015. Simplified critical mudline bending moment spectra of offshore wind turbine support structures. Wind Energy, 12(18), pp. 2171-2197.

Arany, L., Bhattacharya, S., Macdonald, J. \& Hogan, S. J., 2017. Design of monopiles for offshore wind turbines in 10 steps.. Soil dynamics and earthquake engineering, Issue 92, pp. 126-152.

Bhattacharya, S., 2013. Challenges in design of foundations for offshore wind turbines. Engineering \& Technology, 1(1), pp. 1-9.

Bhattacharya, S., 2019. Design of Foundations for Offshore Wind Turbines. 1st ed. s.I.:Wiley.

Bhattacharya, S., Nikitas, G., Arany, L. \& Nikitas, L., 2017. Soil-structure interactions for offshore wind turbines. Engineering\&Technology.

Bhattacharya, S., Nikitas, G. \& Jalbi, S., 2018. On the Use of Scaled Model Tests for Analysis and Design of Offshore Wind Turbines. In: A.M.Krishna, ed. Geotechnics for Natural and Engineered Sustainable Technologies, Developments in Geotechnical Engineering. s.l.:Springer Nature.

Bogard, D. \& Matlock, H., 1980. Simplified calculation of py curves for laterally loaded piles in sand, Houston, TX.: The Earth Technology Corporation, Inc.

Brinch Hansen, J., 1961. The ultimate resistance of rigid piles against. Copenhagen, Danish Geotechnical Institute.

Broms, B., 1964. Lateral resistance of piles in cohesionless soils. Journal of the soil mechanics and foundation divisions, 90(3), pp. 123-158.

Broms, B. B., 1946b. Lateral resistance of piles in cohesive soils. Journal of soil mechanics and foundation division, Volume 90, pp. 27-64.

Carter, J. \& Kulhawi, F., 1992. Analysis of laterally loaded shafts in rock. Journal of geotechnical engineering, Volume 118, pp. 839-855.

Cox, J. \& Bhattacharya, S., 2017. Serviceability of suction caisson founded offshore structures. Proceedings of the Institution of Civil Engineers - Geotechnical Engineering, 170(3), pp. 273-284.

Dawson, T. H., 1983. Offshore structural engineering. s.I.:Prentice-Hall.

Desmond, C., Murphy, J., Blonk, L. \& Haans, W., 2016. Description of an 8 W reference wind turbine. Journal of Physics: Conference Series , 753(9), p. 092013.

DNV, 2014. Offshore standard DNV-OS-J101: Design of offshore wind turbine structures. s.I.:s.n.

Dunnavant, T. W. \& O'Neill, M. W., 1989. Experimental p-y Model for Submerged, Stiff Clay. Journal of geotechnical engineering, 115(1), pp. 95-114. 
Erbrich, C. T., O'Neill, M. P., Clancy, P. \& Randolph, M., 2010. Axial and Lateral Pile Design in Carbonate Soils, Keynote Lecture.. Perth, Proceedings of the 2nd International Symposium on Frontiers in Offshore Geotechnics.

Fleming, W. G. K., Weltman , A. J., Randolph, M. F. \& Elson, W. K., 1992. Piling engineering. 2nd ed. London: Surrey University Press.

Harrabin, R., 2017. Offshore wind power cheaper than new nuclear, 2017: BBC.

Jamiolkowski, M. \& Garassino, A., 1977. Soil modulus for laterally loaded piles. Tokyo, s.n., pp. 87-92.

Leblanc, C., Houlsby, G. \& Byrne, B., 2010. Response of stiff piles in sand to long-term cyclic lateral loading. Géotechnique, 60(2), pp. 79-90.

Lin, S. \& Liao, J., 1999. Permanent strains of piles in sand due to cyclic lateral loads. Journal of geotechnical and geoenvironemntal engineering, pp. 798-82.

Long, J. \& Vanneste, G., 1994. Effects of cyclic lateral loads on piles in sand. Journal of geotechnical engineering , 120(1), pp. 225-244.

Matlock, H., 1980. Corrolations for design of laterally loaded piles in soft clay. Houston, Texas, Offshore Technology Conference.

Morison, J. R., O'Brien, M. P., Johnson, J. W. \& Schaaf, S. A., 1950. Forces exerted by surface waves in piles. Petroleum Transactions, American Institute of Mining Engineering, Volume 189, pp. 149-154.

Nanda, S. et al., 2017. Monopiles subjected to uni- and multi-lateral cyclic loading. Geotechnical Engineering, 170(GE3), pp. 246-258.

Poulos, H. \& Davies, E., 1980. Pile foundation analysis and design. Canada: John Wiley \& Sons.

Prasad, Y. \& Chari, T. R., 1999. Lateral capacity of model rigid piles in cohesionless soils. Soils and Foundations, 39(2), pp. 21-29.

Randolph, M., 1981. The response of flexible piles to lateral loading. Geotechnique, Volume 31, pp. 361-393.

Reese, L. C., Cox, W. R. \& Koop, F. D., 1974. Analysis of laterally loaded piles. Houston, Proceedings of the 6th Offshore Technology Conference.

Reese, L. C. \& Welch, R. C., 1975. Lateral loading of deep foundations in stiff clay. Journal of Geotechnical and Geoenvironmental Engineering, Volume 101.

Rudolph, C., Bienen, B. \& Grabe, J., 2014. Effects of variation of loading direction on the displacement accumulation of large piles under cyclic lateral loads in sand. Canadian Geotechnical Journal, 51(10), pp. 1196-1206.

Rudolph, C., Grabe, J. \& Bienen, B., 2014. Response of monopile under cyclic latral loading with a varying load direction. Proceedings of the 8th international conference on physical modelling in geotechnics. Perth, CRC Press.

Shadlou, M. \& Bhattacharya, S., 2016. Dynamic stiffness of monopiles supporting wind turbine generators. Soil dynamics and earthquake engineering, Volume 88, pp. 15-32.

Siedel, M., 2010. Feasibility of monopiles for large offshore wind turbines. Bremen, Proceedings of the 10th German Wind Energy Conference . 
Stehly, T., Heimiller, D. \& Scott, G., 2017. 2016 Cost of Wind Energy Review. (No. NREL/TP-6A2070363), Golden, CO (United States): National Renewable Energy Lab.(NREL).

Zhang, L., Silva, F. \& Grismala, R., 2005. Ultimate Lateral Resistance to Piles in Cohesionless Soils. Journal of geotechnical and geoenvironmental engineering, pp. 78-83.

IEC 61400: Wind energy generation systems - Part 12-1: Power performance measurements of electricity producing wind turbines

DNGL-ST-0437: Loads and Site Conditions for Wind Turbines

DNV-RP-C205: Environmental conditions and environmental loads 